\title{
Genetic species identification and population structure of Halophila (Hydrocharitaceae) from the Western Pacific to the Eastern Indian Ocean
}

Vy X Nguyen ${ }^{1,2}$, Matsapume Detcharoen ${ }^{3}$, Piyalap Tuntiprapas ${ }^{4}$, U Soe-Htun ${ }^{5}$, Japar B Sidik ${ }^{6}$, Muta Z Harah? Anchana Prathep ${ }^{3}$ and Jutta Papenbrock ${ }^{1 *}$

\begin{abstract}
Background: The Indo-Pacific region has the largest number of seagrass species worldwide and this region is considered as the origin of the Hydrocharitaceae. Halophila ovalis and its closely-related species belonging to the Hydrocharitaceae are well-known as a complex taxonomic challenge mainly due to their high morphological plasticity. The relationship of genetic differentiation and geographic barriers of $\mathrm{H}$. ovalis radiation was not much studied in this region. Are there misidentifications between $\mathrm{H}$. ovalis and its closely related species? Does any taxonomic uncertainty among different populations of $\mathrm{H}$. ovalis persist? Is there any genetic differentiation among populations in the Western Pacific and the Eastern Indian Ocean, which are separated by the Thai-Malay peninsula? Genetic markers can be used to characterize and identify individuals or species and will be used to answer these questions.
\end{abstract}

Results: Phylogenetic analyses of the nuclear ribosomal internal transcribed spacer region based on materials collected from 17 populations in the Western Pacific and the Eastern Indian Ocean showed that some specimens identified as $\mathrm{H}$. ovalis belonged to the H. major clade, also supported by morphological data. Evolutionary divergence between the two clades is between 0.033 and 0.038 , much higher than the evolutionary divergence among H. ovalis populations. Eight haplotypes were found; none of the haplotypes from the Western Pacific is found in India and vice versa. Analysis of genetic diversity based on microsatellite analysis revealed that the genetic diversity in the Western Pacific is higher than in the Eastern Indian Ocean. The unrooted neighbor-joining tree among 14 populations from the Western Pacific and the Eastern Indian Ocean showed six groups. The Mantel test results revealed a significant correlation between genetic and geographic distances among populations. Results from band-based and allele frequency-based approaches from Amplified Fragment Length Polymorphism showed that all samples collected from both sides of the Thai-Malay peninsula were clustered into two clades: Gulf of Thailand and Andaman Sea.

Conclusions: Our study documented the new records of H. major for Malaysia and Myanmar. The study also revealed that the Thai-Malay peninsula is a geographic barrier between $\mathrm{H}$. ovalis populations in the Western Pacific and the Eastern Indian Ocean.

Keywords: Eastern Indian Ocean, Evolution, Genetic distance, Halophila ovalis, Western Pacific Ocean

\footnotetext{
* Correspondence: Jutta.Papenbrock@botanik.uni-hannover.de

'Institute of Botany, Leibniz University Hannover, Herrenhäuserstr. 2, D-30419

Hannover, Germany

Full list of author information is available at the end of the article
} 


\section{Background}

The Indo-Pacific Ocean - the origin of seagrass - has the largest number of seagrass species worldwide with huge meadows of mixed species stands, but the taxonomy of Halophila members is still unclear and genetic variation has not been much investigated so far [1]. In comparison to other seagrass species in the meadows, Halophila ovalis (R. Br.) Hooker is the dominant species and very commonly found in the region. Recently, some new records of Halophila members such as Halophila major (Zoll.) Miquel, were documented in Southeast Asian countries including Indonesia, Viet Nam and Thailand [2,3]. Additionally, $H$. sulawesii J. Kuo was found and described for the first time in Indonesia [4]. Traditional classification of $H$. ovalis and closely related species based on leaf morphological data is very challenging, and species misidentification among Halophila members is reported in various studies $[1,5,6]$. Genetic markers are considered as helpful tools to resolve boundaries between species as well as the genetic variation among populations within species [6-8].

The Indo-Pacific Ocean also shows a high diversity of landscapes, habitats as well as several existing geographic barriers. Geographic isolation refers to a situation where a species, or a population of a species, becomes separated by a physical barrier, allowing each group to diverge along separate evolutionary paths [9]. The effect of geographic isolation is that the two populations are subjected to different selection pressures, since the conditions in the two areas are different [10]. Thus different alleles will be selected and genetic differences will gradually accumulate between the populations. In general, halophytes such as mangroves, marine algae, and seagrass grow in the coastal zone, which is connective between land and sea $[1,11]$. Currents along the coast or ocean currents play an important role for the migration of species from one coastal area to another [7]. Recently, there were several studies published on mangroves $[12,13]$ and animals $[14,15]$ from this region revealing the genetic variation isolated by barriers.

Among the members of Halophila, $H$. ovalis is widespread in the Indo-Pacific Ocean. In the Pacific, it occurs from southern Japan throughout Southeast Asia, many islands of the western Pacific, and through all but the southern coast of Australia, as well as Lord Howe and Norfolk Islands, and as far east as Tonga and Samoa. In the Indian Ocean, $H$. ovalis is found from southwestern Australia to East Africa and the Red Sea, including Madagascar, with the exception of islands or coastlines with no records. Recently, $H$. ovalis has been also discovered in the Atlantic Ocean on the Island of Antigua [16]. The plant is diminutive and lacks strongly lignified tissue, making it flexible, but vulnerable to physical disturbances [7]. Halophila ovalis grows on a variety of substrates and is often the first to colonize newly available sediments
$[5,17]$. The species can grow at a range of temperatures and is distributed from tropical to warm-temperate waters $[16,18]$. This species has a wide depth distribution as well, with individuals growing from the intertidal up to a depth of $30 \mathrm{~m}$ [19]. Like other seagrass species, H. ovalis reproduces vegetatively by branching of rhizomes and the formation of new shoots, and sexually through seeds [11]. Due to high variation of leaf morphology and adaptation, Den Hartog [11] emphasized the need for detailed studies of this species to better understand the link between morphological variability and environmental parameters.

Leaf morphology is used as the main key to identify and name Halophila species [11,20]. However, traits of leaf morphology are overlapping among members of this genus [1]. Recently, genetic markers of plastid sequences have been used to reveal the genetic relationships among the members of the Halophila genus [2,21]. However, the species boundaries could not be fully resolved. Using phylogenetic analyses of the nuclear ribosomal internal transcribed spacer (ITS1-5.8S-ITS2) region showed that some specimens identified as $H$. ovalis belonged to different clades, and this clearly points out the need for critical taxonomic revision of Halophila material from the entire geographic distribution of this genus [7]. This nuclear sequence was also used to identify the genetic relation of $H$. ovalis and closely related species namely H. major, Halophila nipponica J. Kuo, Halophila minor (Zoll.) den Hartog and Halophila hawaiana Doty and B. C. Stone $[6,7,22,23]$.

There are several techniques including isozyme analyses [24,25], Random Amplified Polymorphic DNA (RAPD) [26-29], Amplified Fragment Length polymorphism (AFLP) [30-33] and microsatellites [34,35] to access genetic variation among and between seagrass populations. The major advantage of the AFLP technique is the large number of polymorphisms that the method generates compared with other markers. However, the methodology of AFLP experiments and post-run data analysis are complex and time consuming compared with other markers [36,37]. Microsatellites are simple sequence repeats (SSRs) with advantages like locus-specificity, co-dominance, high degree of polymorphism, and it is also possible to work with partially degraded DNA [38]. So far there is only little information of DNA fingerprinting techniques applied for H. ovalis.

It is hypothesized that (i) taxonomic uncertainty among different populations of $H$. ovalis persists and (ii) geographic distance, differentiation of habitats or the geographic barrier of the Indo-Malay peninsula may affect the genetic variation of $H$. ovalis from the Western Pacific to the Eastern Indian Ocean. The aims of this study are (i) to identify Halophila species collected in Hong Kong, Thailand, Malaysia and India based on the molecular marker (ITS1-5.8S-ITS2) and (ii) to search for the genetic 
structure of $H$. ovalis from the Western Pacific to the Eastern Indian Ocean based on microsatellite and AFLP approaches.

\section{Results}

Species identification based on the nuclear ITS sequences and morphology

Nineteen ITS sequences (Additional file 1) achieved from haplotypes collected at 17 populations of Halophila spp. in the study sites shown in Figure 1 and listed in Table 1 were used for the phylogenetic analysis. The alignment of the sequences received from three independent PCRs revealed that there were no nucleotide differences among replications. Fragments of $18 \mathrm{~S}$ and $28 \mathrm{~S}$ were removed to gain only the sequence of ITS1-5.8S-ITS2 (620-624 bp). A final alignment of $628 \mathrm{bp}$ (including nucleotides and gaps) was generated for ITS1-5.8S-ITS2, of which 43 (6.8\%) were parsimony informative characters, 75 (11.9\%) were variable sites, 549 (87.4\%) were conserved sites, and $32(5.1 \%)$ were singleton sites. Results of the four algorithms applied (maximum likelihood (ML), neighbor joining (NJ), maximum parsimony (MP) and Bayesian analysis (BA)) showed that all samples collected from the 17 populations were distributed into two clades consisting of H. major (clade I) and H. ovalis (clade II) with 98, 100, 96 and $99 \%$ bootstrap values, respectively. There was no difference in the topology of the phylogenetic trees based on these different methods except for small differences in the bootstrap values. In clade I, haplotypes (Hap.) 4, 5, 13, and 16 clustered with known $H$. major sequences. In clade II, the remaining haplotypes clustered with known sequences from $H$. ovalis. None of the samples clustered with known sequences from $H$. minor (Figure 2). The results also showed that nucleotide differences among individuals of the $H$. major clade and among individuals of the $H$. ovalis clade were zero to six nucleotides and zero to three nucleotides, respectively. However, the counts of different nucleotides between the two clades were 19 to 23 . In addition, evolutionary divergence among individuals of the $H$. major clade and among individuals of the $H$. ovalis clade was 0.000 to 0.010 and 0.000 to 0.005 , respectively. Evolutionary divergence between the two clades was 0.033 to 0.038 . The results clearly indicate that haplotypes 4,5 , 13 , and 16 need to be classified as $H$. major and samples collected at TH-tr (Hap. 9) need to be grouped into the $H$. ovalis clade instead with $H$. minor sequences. For both countries, Malaysia and Myanmar, it is the first time that $H$. major was recorded.

The morphological data also supported the results obtained from the molecular ITS data. For the samples identified as $H$. major based on ITS, five characters of leaf morphology including lamina width, lamina length,

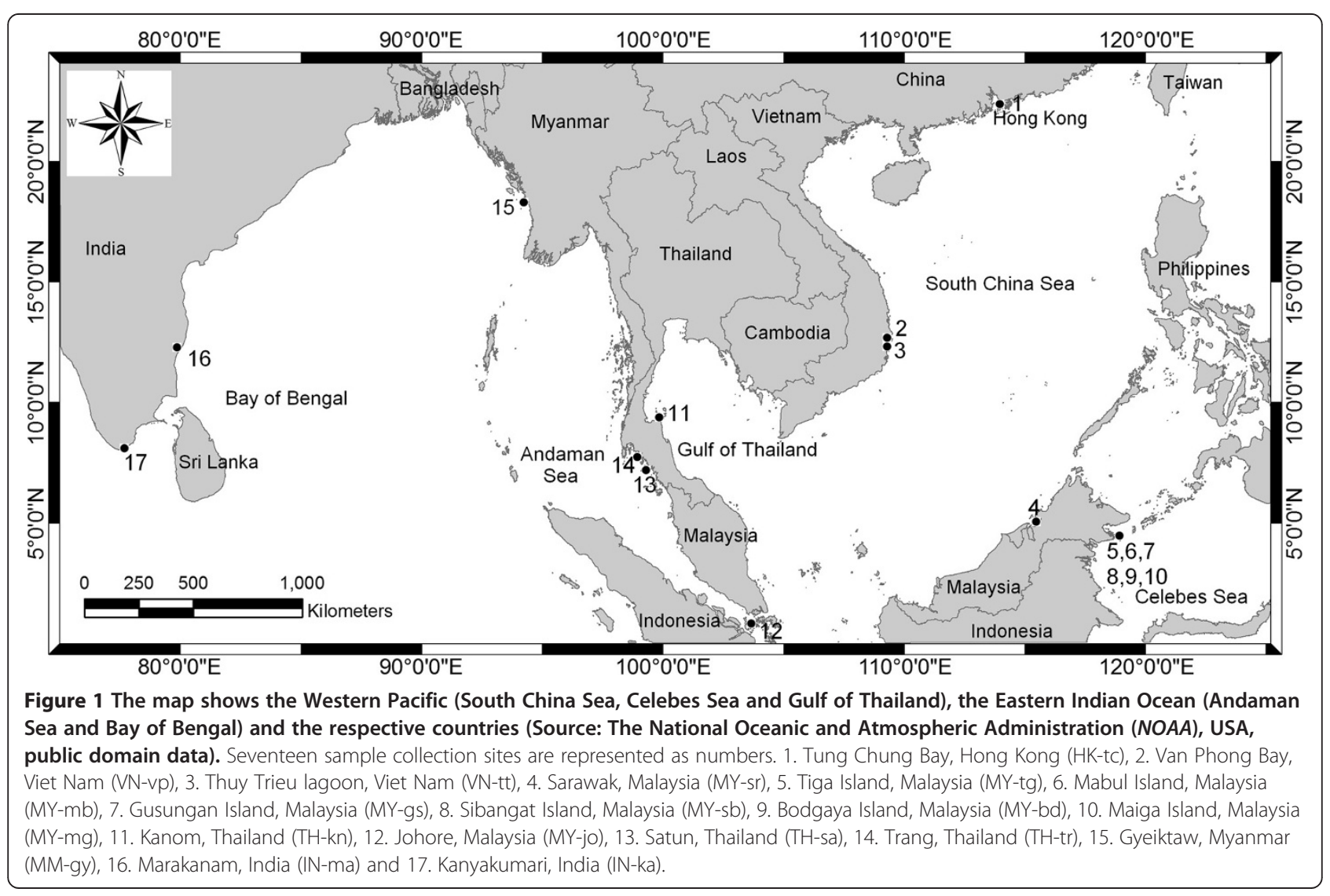


Table 1 Locations/abbreviations, regions, coordinates, sample size and taxa used in this study

\begin{tabular}{|c|c|c|c|c|c|c|c|c|c|}
\hline \multirow[b]{2}{*}{ No. } & \multirow[b]{2}{*}{ Location } & \multirow[b]{2}{*}{ Coordinates (degree) } & \multirow[b]{2}{*}{ Sample size } & \multirow[b]{2}{*}{ Taxon } & \multicolumn{3}{|c|}{ Kind of analysis } & \multirow[b]{2}{*}{ Citations } & \multirow[b]{2}{*}{ GB numbe } \\
\hline & & & & & ITS & AFLP & $\overline{\text { SSRs }}$ & & \\
\hline 1 & $\mathrm{HK}-\mathrm{tc}^{1}$ & $113.9249^{\circ} \mathrm{E} ; 22.2889^{\circ} \mathrm{N}$ & 6 & H. ovalis & X, Hap.1 & & $x$ & This study & KF620337 \\
\hline 2 & VN-vp ${ }^{1}$ & $109.3445^{\circ} \mathrm{E}_{;} 12.1289^{\circ} \mathrm{N}$ & 10 & H. ovalis & $x$ & & $x$ & {$[23]$} & KC175909 \\
\hline 3 & $V N-t^{1}$ & $109.3222^{\circ} \mathrm{E} ; 12.1278^{\circ} \mathrm{N}$ & 10 & H. ovalis & $x$ & & $x$ & {$[23]$} & KC175908 \\
\hline 4 & MY-sr' ${ }^{1}$ & $115.4652^{\circ} \mathrm{E} ; 04.9825^{\circ} \mathrm{N}$ & 5 & H. ovalis & X, Hap. 2 & & $x$ & This study & KF620338 ${ }^{+}$ \\
\hline 5 & MY-tg ${ }^{1}$ & $118.6006^{\circ} \mathrm{E} ; 04.3750^{\circ} \mathrm{N}$ & 5 & H. ovalis & X, Hap. 3 & & $x$ & This study & KF620339+ \\
\hline 6 & $M Y-m b^{1}$ & $118.6265^{\circ} \mathrm{E} ; 04.2479^{\circ} \mathrm{N}$ & 5 & H. major* & X, Hap. 4 & & & This study & KF620340 ${ }^{+}$ \\
\hline 7 & MY-gs ${ }^{1}$ & $118.5458^{\circ} \mathrm{E} ; 04.3161^{\circ} \mathrm{N}$ & 5 & H. major* & X, Hap. 5 & & & This study & KF620341 $1^{+}$ \\
\hline 8 & MY-sb ${ }^{1}$ & $118.6626^{\circ} \mathrm{E} ; 04.5546^{\circ} \mathrm{N}$ & 5 & H. ovalis & X, Hap. 6 & & $x$ & This study & KF620342 ${ }^{+}$ \\
\hline 9 & MY-bd ${ }^{1}$ & $118.7208^{\circ} \mathrm{E} ; 04.6016^{\circ} \mathrm{N}$ & 5 & H. ovalis & X, Hap. 7 & & $x$ & This study & KF620343 ${ }^{+}$ \\
\hline 10 & MY-mg ${ }^{1}$ & $118.6868^{\circ} \mathrm{E} ; 04.6080^{\circ} \mathrm{N}$ & 5 & H. ovalis & X, Hap. 8 & & $x$ & This study & KF620344 ${ }^{+}$ \\
\hline 11 & $\mathrm{TH}-\mathrm{kn}{ }^{1}$ & $099.8802^{\circ} \mathrm{E} ; 09.2128^{\circ} \mathrm{N}$ & 4 & H. major ${ }^{* * *}$ & X, Hap. 9 & $x$ & $x$ & This study & KF620345 \\
\hline 12 & $M Y-j o^{1}$ & $103.1333^{\circ} \mathrm{E} ; 01.3322^{\circ} \mathrm{N}$ & 5 & H. ovalis & X, Hap. 10 & & $x$ & This study & KF620346 ${ }^{+}$ \\
\hline 13 & $\mathrm{TH}-\mathrm{sa}^{2}$ & $099.7586^{\circ} \mathrm{E} ; 06.7824^{\circ} \mathrm{N}$ & 9 & H. ovalis & X, Hap. 11 & $x$ & $x$ & This study & KF620347 ${ }^{+}$ \\
\hline \multirow[t]{4}{*}{14} & $\mathrm{TH}-\mathrm{tr}^{2}$ & & & & & & & & \\
\hline & Site 1 & $099.3159^{\circ} \mathrm{E} ; 07.3745^{\circ} \mathrm{N}$ & 5 & H. ovalis & X, Hap. 12 & $x$ & $x$ & This study & KF620348 ${ }^{+}$ \\
\hline & Site 2 & $099.3159^{\circ} \mathrm{E} ; 07.3745^{\circ} \mathrm{N}$ & 6 & H. ovalis** & X, Hap. 13 & $x$ & $x$ & & KF620349 ${ }^{+}$ \\
\hline & Site 3 & $099.3389^{\circ} \mathrm{E} ; 07.3829^{\circ} \mathrm{N}$ & 5 & H. ovalis & X, Hap. 14-15 & & & & KF620350-1 $1^{+}$ \\
\hline 15 & $M M-g y^{2}$ & $094.3393^{\circ} \mathrm{E} ; 18.3650^{\circ} \mathrm{N}$ & 7 & H. major* & X, Hap. 16 & & & This study & KF620352 $2^{+}$ \\
\hline 16 & $\mathrm{IN}-\mathrm{ma} \mathrm{a}^{2}$ & $079.9790^{\circ} \mathrm{E} ; 12.2330^{\circ} \mathrm{N}$ & 10 & H. ovalis & X, Hap. 17-18 & & $x$ & This study & KF620354-5 \\
\hline \multirow[t]{4}{*}{17} & $\mid \mathrm{N}-\mathrm{ka} \mathrm{a}^{2}$ & $077.5640^{\circ} \mathrm{E} ; 08.1001^{\circ} \mathrm{N}$ & 10 & H. ovalis & X, Hap. 19 & & $x$ & This study & KF620353 \\
\hline & & & & H. decipiens & $x$ & & & [23] & KC175913 \\
\hline & & & & H. minor & $x$ & & & {$[7]$} & AF366405 $5^{+}$ \\
\hline & & & & H. minor & $x$ & & & {$[7]$} & AF366406 ${ }^{+}$ \\
\hline
\end{tabular}

There are 122 individuals collected from 17 populations in the Western Pacific and the Eastern Indian Ocean. X: genetic marker used for the populations. ${ }^{*}{ }^{* *},{ }^{* * *}$ : First identification as $H$. ovalis, $H$. minor and H. major, respectively. Hap. 1-19: Haplotypes $1-19$. Abbreviations as in Figure $1 .{ }^{1}$ Pacific Ocean, ${ }^{2}$ Indian Ocean.

${ }^{+}$Accession number for sequences deposited in GenBank.

number of cross-veins, space between intra-marginal veins, and especially the ratio of the distance between intra-marginal vein $(r)$ and lamina margin $(R)$ showed clear differences in comparison to $H$. ovalis. The ratio of the distance between the intra-marginal vein and the lamina margin was $1: 20.8$ to $1: 25.6$. In contrast, this ratio was 1:12 to $1: 16$ in $H$. ovalis [4]. Moreover, the number of paired cross veins of $H$. major was 18 to 20 and therefore higher than the number of paired cross veins in $H$. ovalis (14 to 17) [4]. The p-values obtained from Levene's test of lamina width, lamina length, number of paired cross veins were lower than 0.05 (heteroscedasticity). In contrast, the $\mathrm{p}$-values obtained from Levene's test of the ratio $r / R$ was higher than 0.05 (homoscedasticity). Single factor ANOVA shows that for the ratio $(r / R)$ significant differences can be observed among the collection sites $\left(\mathrm{F}=77.82>\mathrm{F}_{\text {crit. }}\right.$, $\mathrm{p}<0.001$ ). Details resulting from multiple comparisons of each trait obtained by the Tukey test showed that there were significant differences of the ratio $(r / R)$ between populations at MY-mb, MY-gs, MM-gt (H. major) and the remaining populations ( $H$. ovalis). Details of comparisons of the leaf morphology of $H$. major and $H$. ovalis are presented in Table 2 and Figure 3.

\section{Genetic diversity and population structure of $H$. ovalis from the Western Pacific to the Eastern Indian Ocean Genetic diversity}

Data on observed heterozygosity $\left(\mathrm{H}_{\mathrm{o}}\right)$, expected heterozygosity $\left(\mathrm{H}_{\mathrm{e}}\right)$ and allelic richness $(\mathrm{A})$ are presented in Table 3. Among populations, the highest expected heterozygosity $\left(\mathrm{H}_{\mathrm{e}}\right)$ or genetic diversity in the Western Pacific and the Indian Ocean were found at MY-jo and TH-sa, respectively. The lowest expected genetic diversity in the Western Pacific and Indian Ocean were observed at HK-tc and IN-ma, respectively. Genetic diversity of the populations in the Western Pacific Ocean was slightly higher than of the populations in the Indian Ocean (0.306 vs 0.289 ). However, there was no significant difference between the oceanic systems $(t$-test, $\mathrm{p}=0.78)$. Likewise, observed heterozygosity and allelic richness in the Western Pacific 


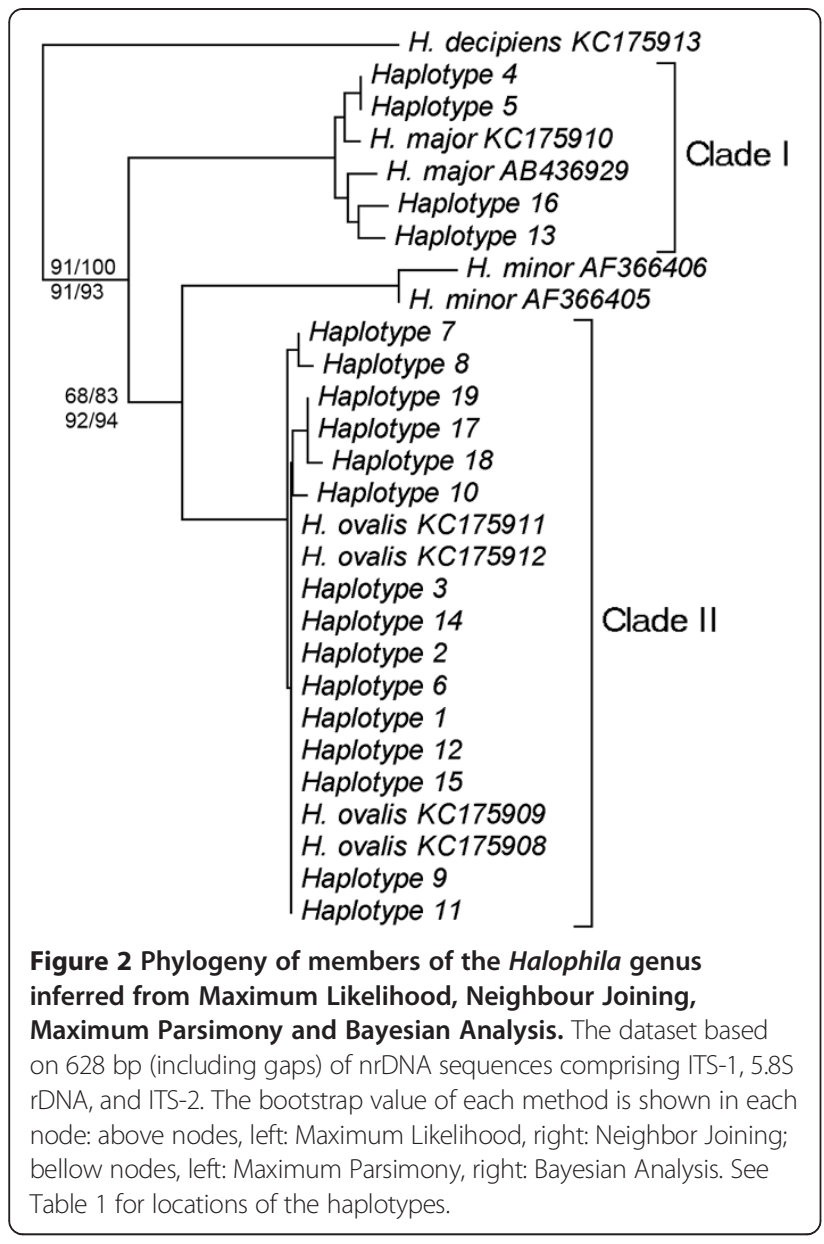

were slightly higher than in the Indian Ocean (0.552 vs 0.542 and 1.560 vs 1.550 , respectively). For the observed heterozygosity and allelic richness, there was no statistically significant difference between both oceanic systems ( $t$-test, $\mathrm{p}=0.926$ and 0.929 , respectively).

\section{Population structure}

Halophila ovalis populations were markedly differentiated from each other in the Western Pacific and the Eastern Indian Ocean (Table 4). For the Western Pacific region (South China Sea, Celebes Sea and Gulf of Thailand), a significant genetic differentiation among investigated populations was observed.

For the Western Pacific Ocean, genetic distances among populations in regions I, II, III, IV, V and VI (see Table 1 and Figure 1 for abbreviations) were very high. In detail, the genetic distance between region I and III was the highest (2.636). There were lower genetic distances between region II and region V (0.288 to 0.377$)$. However, the genetic distance between II and VI was lower than the genetic distance between VI and III (0.327 to 0.337 vs 0.444$)$. Within region II, the genetic distance between $\mathrm{VN}$-vp and VN-tt (see Table 1 for abbreviations) was 0.221 . In contrast, genetic distances among populations greatly varied from population to population, ranking from 0.05 to 0.818 , in which the genetic distance between MY-mg and MY-bd was the lowest and the genetic distance between MY-sb and MY-tg was the highest (Table 4). Results of AMOVA for SSRs variation of $H$. ovalis populations in the Western Pacific Ocean showed significant differentiation among groups $(\mathrm{p}<0.01)$, among populations within groups $(\mathrm{p}<0.01)$ and within populations $(\mathrm{p}<0.01)$ (Table 5). Hence, high genetic distance and statistical differences were not only found among regions, but also among populations in the Western Pacific Ocean. The overall genetic variation from the Halophila populations in the Western Pacific Ocean was 0.438 calculated from FSTAT.

For the Eastern Indian Ocean, a very high genetic distance between the two regions VII and IX, ranking from 0.731 to 1.296 was observed (Table 4). For the Andaman Sea, the genetic distance between two populations, TH-sa and TH-tr, was determined as zero and non-significant $(p=0.53)$. In contrast, the genetic distance between IN-ma and IN-ka was very high and significantly different $(1.280, \mathrm{p}<0.001)$. The results of AMOVA for SSRs variation of $\mathrm{H}$. ovalis populations in the two regions VII and IX (see Table 1 for abbreviations) indicated that the percentage of variations among groups, among populations within groups and within populations were 20.85, 28.74 and $50.41 \%$, respectively. Significant difference was just

Table 2 Comparisons of leaf morphology characteristics of $\boldsymbol{H}$. major collected in this study and published data from H. ovalis

\begin{tabular}{|c|c|c|c|c|c|}
\hline \multirow[t]{2}{*}{ Characteristic } & \multicolumn{5}{|l|}{ Species } \\
\hline & H. ovalis & H. major MY-mb & H. major MY-gs & H. major MM-gy & H. major \\
\hline Lamina width (mm) & $5-20$ & $12-15$ & $12-15$ & 13 & $9-11$ \\
\hline Lamina length $(\mathrm{mm})$ & $10-40(-70)$ & $18-22$ & $18-22$ & 22 & $15-25$ \\
\hline No. of cross veins & $10-25$ & $18-20$ & $18-20$ & 20 & $14-17$ \\
\hline Space between intramaginal vein $(\mathrm{mm})$ & $0.1-0.3$ & $0.25-0.3$ & $0.25-0.3$ & 0.3 & 0.2 \\
\hline $\begin{array}{l}\text { Half lamina width: distance between intramarginal veins and } \\
\text { lamina margin ration }\end{array}$ & $1: 12-16$ & $1: 21-22$ & $1: 21-22$ & $1: 20$ & $1: 20-25$ \\
\hline Source & {$[5]$} & This study & This study & This study & {$[5]$} \\
\hline
\end{tabular}




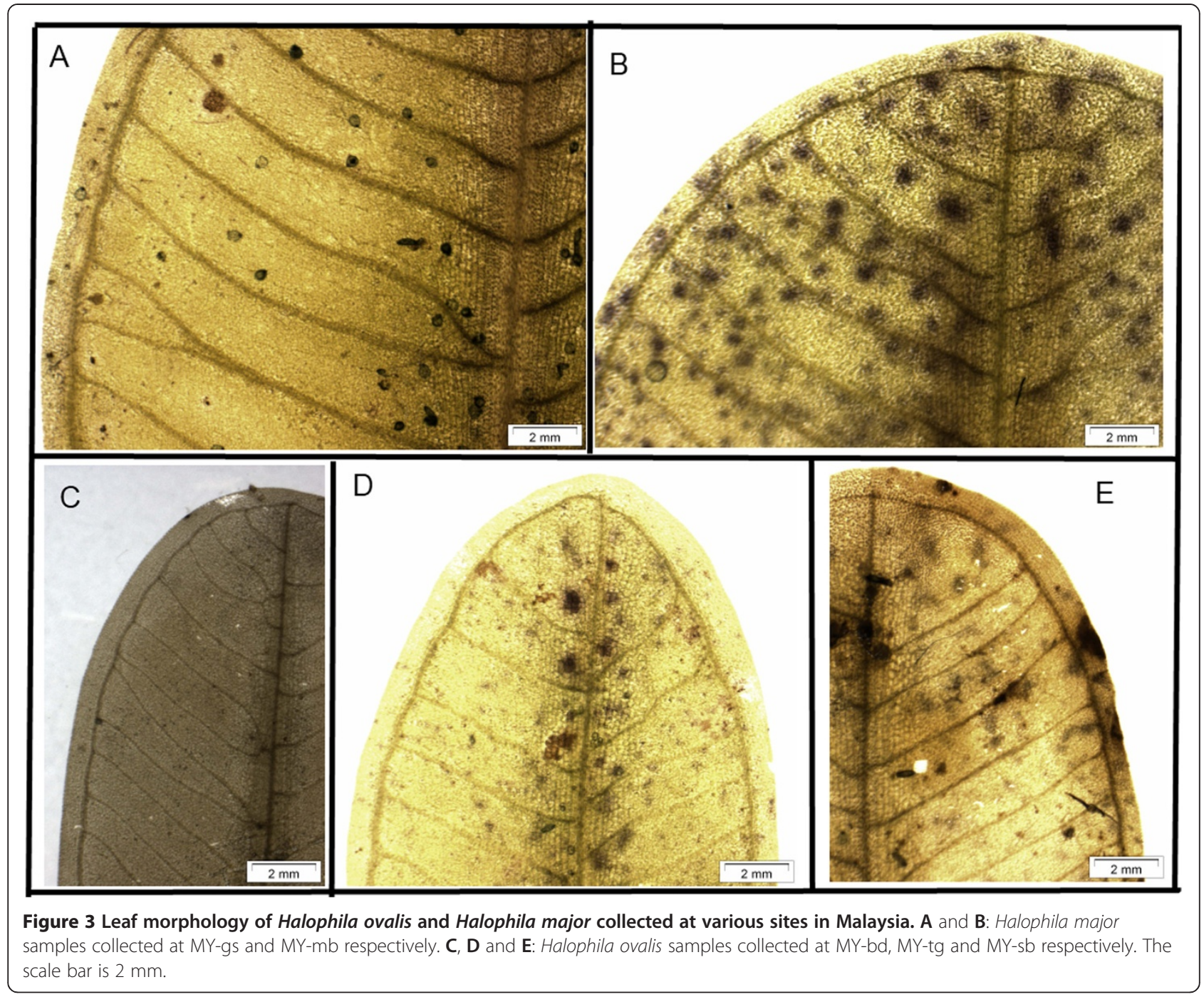

found among groups and among populations within groups $(\mathrm{p}<0.01)$ and there were no significant differences within populations $(\mathrm{p}=0.5)$. Moreover, the results of AMOVA for SSRs variation of $H$. ovalis populations in both oceanic systems (Western Pacific vs Eastern Indian) showed significant differences among groups $(\mathrm{p}<0.01)$, among populations within groups $(\mathrm{p}<0.01)$, and within populations $(\mathrm{p}<0.01)$. The overall genetic variation from the Halophila populations in the Eastern Indian Ocean was 0.485 calculated from FSTAT.

The unrooted neighbor-joining tree among 14 populations from eight regions in the Western Pacific and Eastern Indian Ocean showed six main groups including group 1 Region I: Northern part of the South China Sea (HK), group 2 - Region II and V: Western part of the South China Sea and the Gulf of Thailand (VN-vp, VN-tt and TH-kn), group 3 - Region III and IV: Eastern part of the South China Sea and the Celebes Sea (MY-sr, MY-sb, MY-mg, MY-db and MY-tg), group 4 - Region 6: Southern part of the South China Sea (MY-jo), group 5 - Region VII: Andaman Sea (TH-tr and TH-sa) and group $6-$ Region IX: Bay of Bengal (IN-ma and IN-ka) (Figure 4). The multi-locus estimate of spatial differentiation among 14 populations relative to the whole sampled distribution was large $\left(\mathrm{F}_{\mathrm{ST}}=0.679\right)$. The correlation between geographic and genetic distances in the study area is presented in Figure 5. The result of the Mantel test showed that the geographic distance was linearized and plotted against the geographic distances between populations $(r=0.578$, $\mathrm{P}_{\text {Mantel }}<0.0001$, the significance level $\alpha=0.05$ ). An approximately linear increase in Slatkin's genetic distance with increasing geographic distance between all pairs of populations confirmed a simple model, namely differentiation-by-distance.

Based on 15 ITS sequences from $H$. ovalis, there are eight distinct haplotypes found in 14 populations (populations from MM-gy, MY-mb, and MY-gs were rejected because these samples were classified as $H$. major). 
Table 3 Comparison of genetic diversity among $\boldsymbol{H}$. ovalis populations

\begin{tabular}{|c|c|c|c|c|}
\hline Oceanic system & Population & Observed heterozygosity $\left(\mathrm{H}_{\mathrm{o}}\right)$ & Expected heterozygosity $\left(\mathrm{H}_{\mathrm{e}}\right)$ & Allelic richness (A) \\
\hline & HK-tc & 0.200 & 0.109 & 1.2 \\
\hline & VN-vp & 0.800 & 0.421 & 1.8 \\
\hline & VN-tt & 0.600 & 0.316 & 1.6 \\
\hline & MY-sr & 0.200 & 0.111 & 1.2 \\
\hline & MY-tg & 0.600 & 0.333 & 1.6 \\
\hline \multirow[t]{8}{*}{ Pacific } & MY-sb & 0.520 & 0.316 & 1.6 \\
\hline & MY-bd & 0.600 & 0.333 & 1.6 \\
\hline & MY-mg & 0.600 & 0.333 & 1.6 \\
\hline & TH-kn & 0.600 & 0.343 & 1.6 \\
\hline & MY-jo & 0.800 & 0.444 & 1.8 \\
\hline & Mean (SE) & $0.552(0.206)$ & $0.306(0.112)$ & $1.560(0.207)$ \\
\hline & $\mathrm{TH}$-sa & 0.600 & 0.320 & 1.6 \\
\hline & TH-tr & 0.567 & 0.310 & 1.6 \\
\hline \multirow[t]{3}{*}{ Indian } & IN-ma & 0.400 & 0.211 & 1.4 \\
\hline & IN-ka & 0.600 & 0.316 & 1.6 \\
\hline & Mean (SE) & $0.542(0.096)$ & $0.289(0.053)$ & $1.550(0.100)$ \\
\hline
\end{tabular}

Genetic diversity gained from 14 populations in the Western Pacific $(N=10)$ and the Indian Ocean $(N=4)$. Abbreviations as in Figure 1. Calculation was carried out by the excel microsatellite toolkit [39] and FSTAT [40].

Haplotype I (including Hap. 1, 2, 3, 6, 9, 11, 12 and 14) commonly occurred in the South China Sea, Celebes Sea and Andaman Sea. Haplotypes II (Hap. 7) and III (Hap. 8) were found in MY-bd and MY-gm (Celebes Sea), respectively, and haplotype IV (Hap. 10) in MY-jo only. In the Andaman Sea, there was one more haplotype present haplotype V (Hap. 15). Three haplotypes (VI, VII and VIII) that did not occur in the South China Sea, Celebes Sea and Andaman Sea were found in the Bay of Bengal. Haplotype VI (Hap. 19) was identified in IN-ka, while haplotypes VII (Hap. 17) and VIII (Hap. 18) were detected in IN-ma (Figure 6).

For the AFLP analysis, the genetic similarities (Dice index) among the 24 individual $H$. ovalis samples were estimated based on the number of common fragments ranged from 0.560 to 0.928 . It also showed that the

Table 4 Pairwise comparison of population differentiation among $H$. ovalis populations

\begin{tabular}{|c|c|c|c|c|c|c|c|c|c|c|c|c|c|c|}
\hline & HK-tc & VN-vp & VN-tt & MY-sr & MY-tg & MY-sb & MY-bd & MY-mg & TH-kn & MY-jo & TH-sa & TH-tr & IN-ma & IN-ka \\
\hline HK-tc & - & 0.912 & 1.183 & 2.636 & 1.100 & 1.879 & 1.100 & 1.100 & 1.146 & 0.870 & 0.794 & 0.691 & 2.529 & 1.183 \\
\hline VN-vp & $0.477^{* *}$ & - & 0.221 & 0.858 & 0.434 & 0.591 & 0.434 & 0.561 & 0.288 & 0.508 & 0.741 & 0.791 & 1.375 & 1.036 \\
\hline $\mathrm{VN}-\mathrm{tt}$ & $0.542^{* *}$ & $0.181^{* *}$ & - & 1.325 & 0.547 & 0.900 & 0.547 & 0.858 & 0.377 & 0.485 & 1.046 & 1.078 & 1.850 & 1.375 \\
\hline MY-sr & $0.725^{* *}$ & $0.462^{* *}$ & $0.56^{* *}$ & - & 0.800 & 0.594 & 0.350 & 0.350 & 1.535 & 0.800 & 0.953 & 0.918 & 2.725 & 1.725 \\
\hline MY-tg & $0.524^{* *}$ & $0.303^{* *}$ & $0.354^{* *}$ & $0.444^{* *}$ & - & 0.818 & 0.200 & 0.350 & 0.332 & 0.157 & 0.688 & 0.723 & 1.525 & 0.703 \\
\hline MY-sb & $0.653^{* *}$ & $0.372^{* *}$ & $0.474^{* *}$ & $0.373^{* *}$ & $0.450^{* *}$ & - & 0.356 & 0.356 & 1.103 & 0.816 & 1.169 & 1.211 & 2.168 & 1.502 \\
\hline MY-bd & $0.524^{* *}$ & $0.303^{* *}$ & $0.354^{* *}$ & $0.259^{*}$ & $0.167^{*}$ & $0.263^{* *}$ & - & 0.050 & 0.480 & 0.286 & 0.688 & 0.723 & 1.525 & 1.014 \\
\hline MY-mg & $0.524^{* *}$ & $0.360^{* *}$ & $0.462^{* *}$ & $0.259^{* *}$ & $0.259^{*}$ & $0.263^{* *}$ & $0.048^{* *}$ & - & 0.628 & 0.414 & 0.688 & 0.723 & 1.525 & 1.014 \\
\hline TH-kn & $0.534^{* *}$ & $0.223^{* *}$ & $0.274^{* *}$ & $0.605^{* *}$ & $0.249^{*}$ & $0.524^{*}$ & $0.324^{* *}$ & $0.386^{* *}$ & - & 0.388 & 0.976 & 1.022 & 1.538 & 0.686 \\
\hline MY-jo & $0.465^{* *}$ & $0.337^{* *}$ & $0.327^{* *}$ & $0.444^{*}$ & $0.136^{* *}$ & $0.449^{* *}$ & $0.222^{* *}$ & $0.293^{* *}$ & $0.279^{* *}$ & - & 0.464 & 0.508 & 1.150 & 0.765 \\
\hline TH-sa & $0.443^{* *}$ & $0.425^{* *}$ & $0.511^{* *}$ & $0.488^{* *}$ & $0.408^{* *}$ & $0.539^{* *}$ & $0.408^{* *}$ & $0.408^{* *}$ & $0.494^{* *}$ & $0.317^{* *}$ & - & 0.000 & 1.296 & 0.731 \\
\hline TH-tr & $0.409^{* *}$ & $0.442^{* *}$ & $0.519^{* *}$ & $0.479^{* *}$ & $0.42^{* *}$ & $0.548^{* *}$ & $0.420^{* *}$ & $0.420^{* *}$ & $0.506^{* *}$ & $0.337^{* *}$ & $-0.05^{\mathrm{ns}}$ & - & 1.280 & 0.731 \\
\hline IN-ma & $0.717^{* *}$ & $0.579^{* *}$ & $0.649 * *$ & $0.732^{* *}$ & $0.604^{* *}$ & $0.684^{* *}$ & $0.604^{* *}$ & $0.604^{* *}$ & $0.606^{* *}$ & $0.535^{* *}$ & $0.564^{* *}$ & $0.561^{* *}$ & - & 1.280 \\
\hline IN-ka & $0.542^{* *}$ & $0.509^{* *}$ & $0.579^{* *}$ & $0.633^{* *}$ & $0.413^{* *}$ & $0.600^{* *}$ & $0.503^{* *}$ & $0.503^{* *}$ & $0.407^{* *}$ & $0.433^{* *}$ & $0.422^{* *}$ & $0.422^{* *}$ & $0.561^{* *}$ & - \\
\hline
\end{tabular}

Genetic differentiation $\mathrm{F}_{\mathrm{ST}}$ (below diagonal) and Slatkin's genetic distance [41] derived from 14 populations. Statistical significance based on a comparison-wise error rate of $a=0.05$ (below diagonal). ns $=$ non-significant, ${ }^{*} 0.05 \geq p>0.01,{ }^{* *} p<0.01$. Abbreviations as in Figure 1 . Data was implemented by Arlequin version $3.5[42]$. 
Table 5 AMOVA (Analysis of Molecular Variance) [43] results for SSR variation at 14 collection sites of $H$. ovalis

\begin{tabular}{|c|c|c|c|c|c|}
\hline Source of variation & d.f. & Sum of squares & Variance of components & Percentage of variation & Probability \\
\hline Among groups & 1 & 46.1 & 0.27 & 17.25 & $p<0.01^{*}$ \\
\hline Among populations within groups & 12 & 98.4 & 0.54 & 34.34 & $p<0.01^{*}$ \\
\hline Within populations & 186 & 140.9 & 0.76 & 48.41 & $p<0.01^{*}$ \\
\hline
\end{tabular}

Group 1 are the populations from the Western Pacific Ocean and group 2 from the Eastern Indian Ocean. Calculations were conducted in Arlequin 3.5.1.3 [42].

*Significantly different.

similarity values of the populations within the Andaman Sea (TH-tr and TH-sa) and within the Gulf of Thailand ( $\mathrm{TH}-\mathrm{kn}$ ) were 0.565 to 0.928 and 0.624 to 0.822 , respectively. The similarity values between the populations of $\mathrm{TH}$-tr and TH-sa were higher than between the population of TH-tr and TH-kn (0.634 to 0.820 vs 0.582 to 0.731).

The cluster analysis (Figure 7) revealed that $H$. ovalis populations were divided into two groups, either collected in the Gulf of Thailand or in the Andaman Sea (100\% bootstrap value). However, results of clustering individuals of TH-tr and TH-sa were not significant. The plot of a principal coordinate analysis (PCoA), based on individual genetic distances calculated with 208 AFLP markers, is presented in Additional file 2. The first two axes explained $71.8 \%$ and $3.0 \%$ of the variation, respectively (explaining $74.8 \%$ of total variability). As axis two explained $3 \%$ of variance only, it is evident that the remaining axes contribute poorly to explain the variance. Results of PCoA also indicated that $H$. ovalis was clearly distributed in two main clades: Gulf of Thailand clade and Andaman Sea clade.

Based on the above results, the entire samples were organized in two groups: Gulf of Thailand and Andaman Sea group. Gene diversity $(\mathrm{H})$ [49] of the entire sample set calculated using POPGENE was $0.272 \pm 0.172$, while the value of $\mathrm{G}_{\mathrm{ST}}$ [49] was 0.190. Results of AMOVA analysis revealed that genotypic variation was attributable to

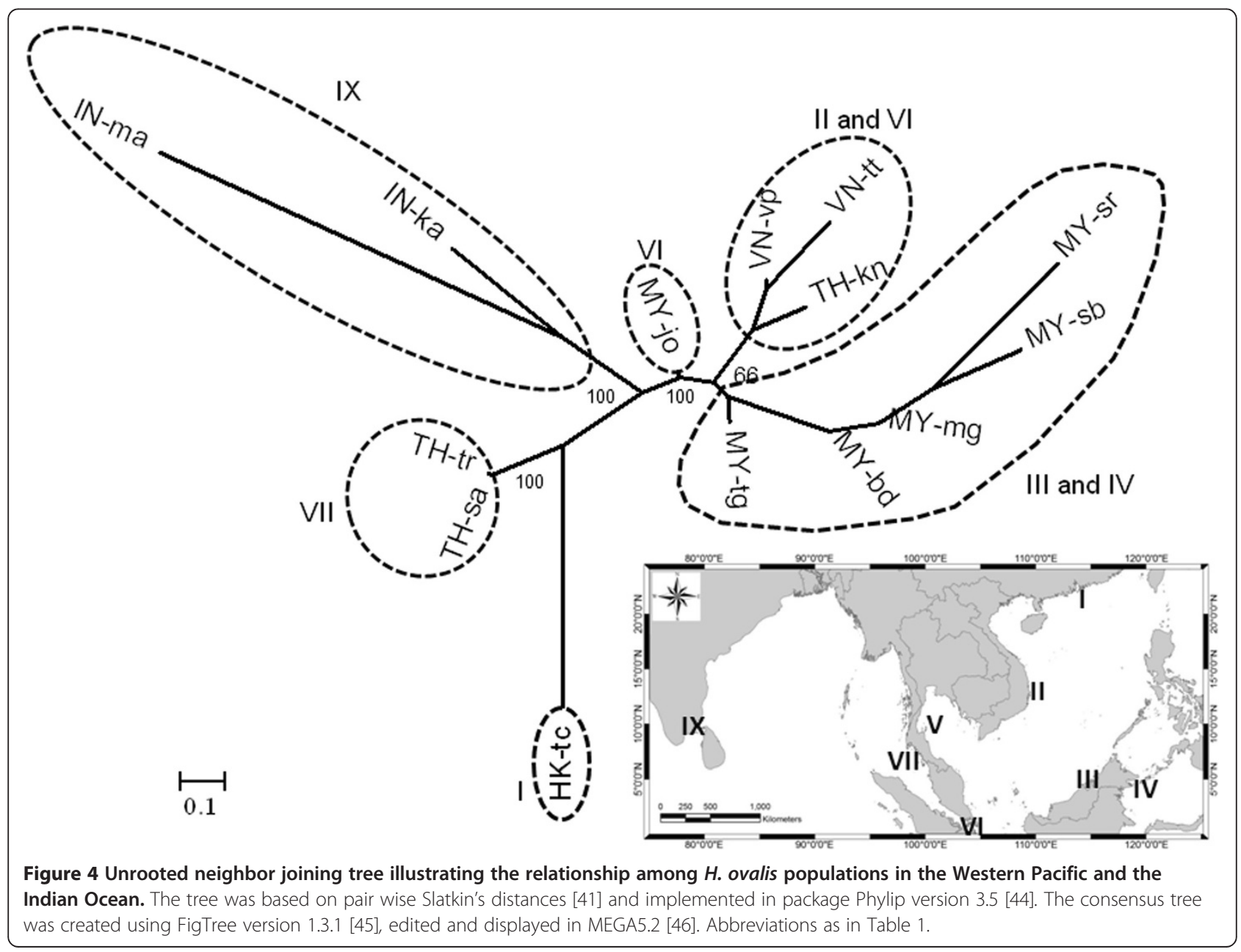




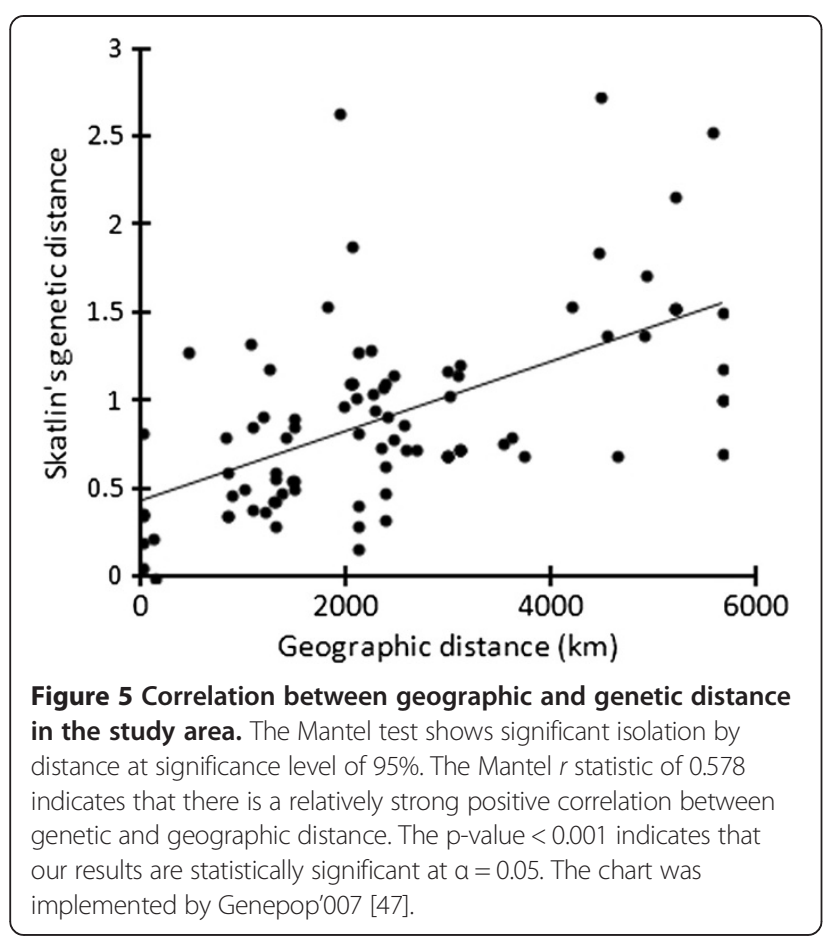

differentiation between the two groups. The majority of variation among groups was $20.47 \%(\mathrm{p}<0.01)$ (Table 6). The matrix of genetic differentiation $\left(\mathrm{F}_{\mathrm{ST}}\right)$ among populations of $H$. ovalis revealed that the genetic distance between TH-tr and TH-sa populations $(0.137, \mathrm{p}<0.01)$ was lower than between TH-tr and TH-kn populations $(0.335$, $\mathrm{p}<0.01)$. The dendrogram based on Nei's genetic distance also showed that three populations were divided into two main clades: 1) Gulf of Thailand and 2) Andaman Sea (Additional file 3). All data are stored in TreeBASE (http://purl.org/phylo/treebase/phylows/ study/TB2:S15597).

\section{Discussion}

The present study is the first report of genetic diversity, as well as genetic differences, within and among populations of $H$. ovalis collected from the Western Pacific Ocean to the Eastern Indian Ocean using nuclear sequence comparison (ITS) and two DNA fingerprinting approaches: AFLP and SSRs. Conformation of new records for H. major in Malaysia and Myanmar and detection of high levels of polymorphism underlined impressively that genetic markers are powerful tools for species identification and assessing genetic diversity in seagrass.

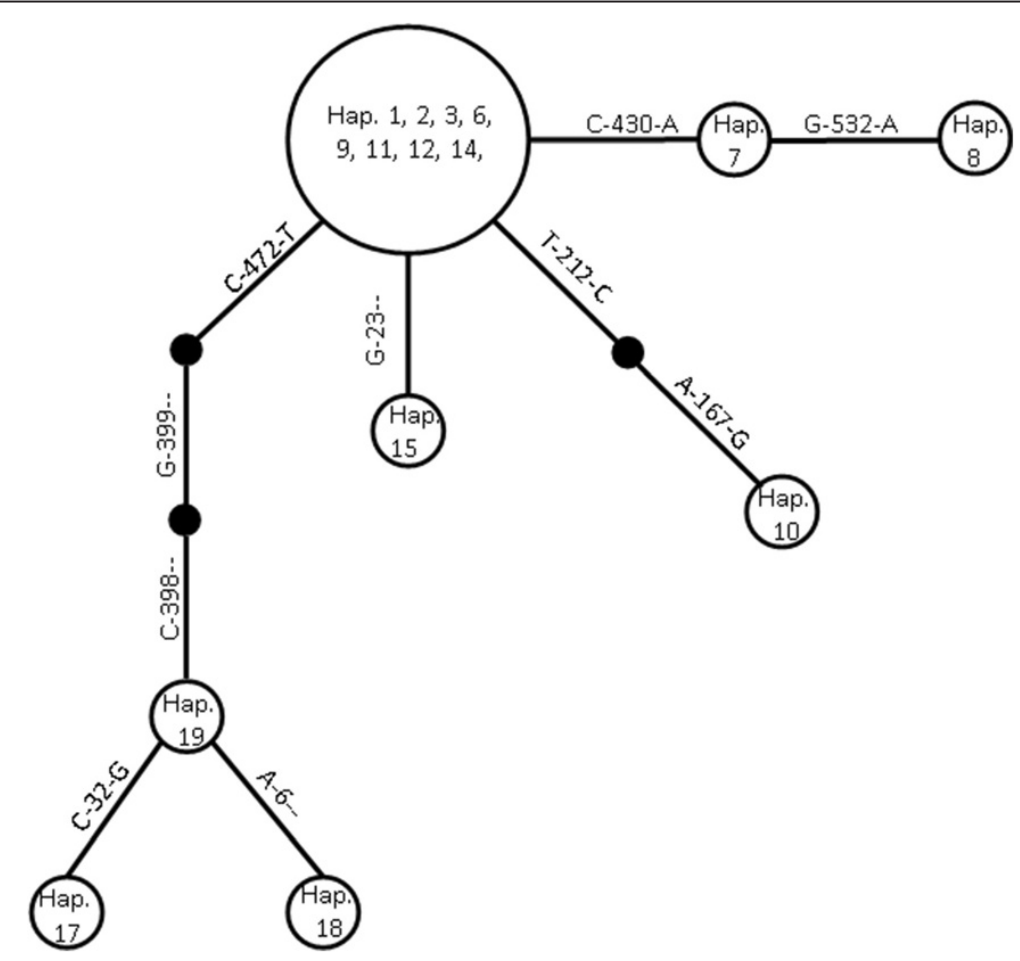

Figure 6 Haplotype network of eight distinct haplotypes and their distribution detected for Halophila ovalis in both Western Pacific and Indian Ocean. Haplotypes are presented by abbreviations in the circles. Abbreviations as in Table 1. Small solid circles are missing haplotypes. Nucleotide position and differences of nucleotide between two haplotypes are presented in each node. The dendrogram was implemented by software TCS version 1.21 [48]. 


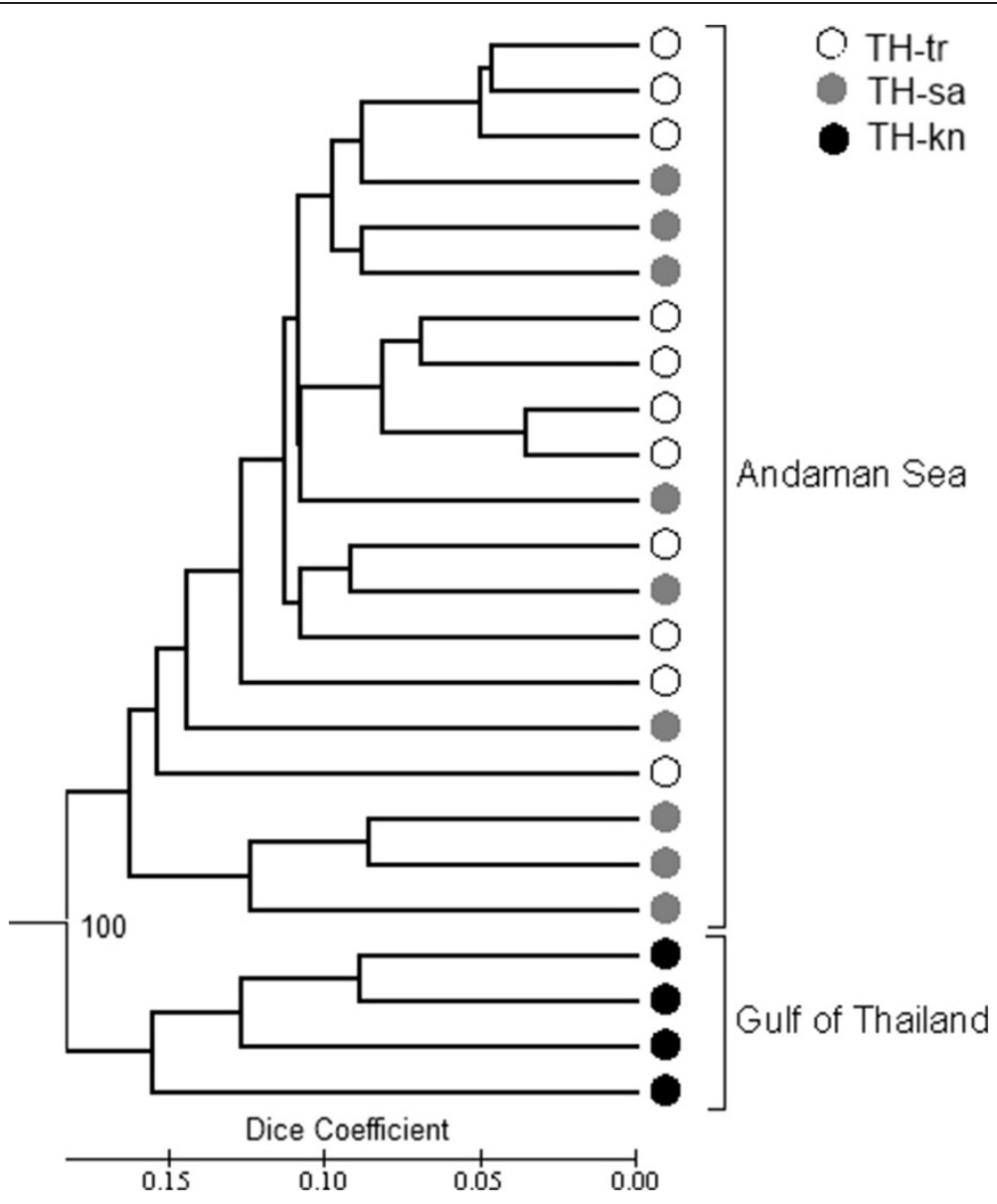

Figure 7 UPGMA-based dendrogram of $\boldsymbol{H}$. ovalis and closely related species generated from 208 AFLP markers. The individuals collected in the Andaman Sea and the Gulf of Thailand were divided into two groups with a 100\% bootstrap value. There are no significant differences between TR and SA populations. Abbreviations as in Figure 1. The dendrogram was assessed by FreeTree [45] and edited by MEGA5.2 [46].

\section{New records of Halophila major for Malaysia and} Myanmar

Variation of leaf morphology has been detected within several species of the Halophila genus, namely $H$. ovalis [50,51], H. hawaiana [22], and H. nipponica [6]. Short et al. $[1,52]$ argued that the taxonomy of $H$. major was unclear, because of overlapping leaf characteristics between $H$. ovalis and $H$. major. Molecular markers, especially ITS, were shown to be a valuable tool in resolving genetic relationships among the species of Halophila. For instance, Halophila euphlebia Makino was once treated as synonym for $H$. ovalis $[11,53]$; then, this species was transferred to $H$. major [8]. Results of Uchimura et al. [3] and Shimada et al. [6] supported the conclusion of Kuo et al. [5] that $H$. major and $H$. ovalis are distinct species based on ITS analysis and morphological data. Recently, Short et al. [1] suggested that species in general should be accepted as a new species only if a complete published taxonomic description existed, documenting unique sexual reproductive characters and significant genetic differences. There are three and six species of Halophila currently reported in Myanmar and Malaysia, respectively, [17,54] not including $H$. major. Halophila major has been found in the recent years along the coastlines of Southeast Asian countries including Indonesia, Thailand, Viet Nam and Japan [3,23]. As

Table 6 AMOVA (Analysis of Molecular Variance) [43] results for AFLP variation at three collection sites of $H$. ovalis

\begin{tabular}{cccccc}
\hline Source of variation & d.f. & Sum of squares & Variance of components & Percentage of variation & Probability \\
\hline Among groups & 1 & 102.9 & 8.1 & 4.3 & 20.47 \\
Among populations within groups & 1 & 69.7 & 210.79 \\
Within populations & 21 & 572.8 & 27.3 & $0.01^{*}$ \\
\hline
\end{tabular}

Group 1 are the populations from the Gulf of Thailand and group 2 from the Andaman Sea. Calculations were conducted in Arlequin 2.2 [42].

*Significantly different. 
it was demonstrated recently that Halophila members could not be fully resolved among closely related species such as $H$. ovalis, $H$. major and $H$. ovata Gaudich based on concatenated sequences of the two plastid markers $r b c \mathrm{~L}$ and $m a t \mathrm{~K}[2,21]$. In contrast, the phylogenetic analysis of the nuclear ITS sequence indicated that $H$. ovalis, $H$. major and $H$. minor are distinct species $[3,7,23]$. Hence, the use of the ITS marker to classify the entire set of samples collected for this study is the best choice based on the current knowledge. In this study, cluster analysis, direct comparison of nucleotide differences and evolutionary divergence between the two clades $\mathrm{H}$. ovalis and $\mathrm{H}$. major revealed that the materials collected in Mabul Island (MY-mb) and Gusungan Island (MY-gs), both in Malaysia, and one population (MM-gy) in Myanmar differ significantly from the $H$. ovalis clade. Moreover, four methods of constructing phylogenic trees also indicated that materials collected in Mabul Island and Gusungan Island (both in Malaysia) and Myanmar are H. major. Only the indications of the molecular methods initiated a detailed microscopic analysis of the leaf samples. The leaf morphology based on the ratio of the distance between the intra-marginal vein and the lamina margin confirmed the ITS analysis. Hence, morphological and nuclear sequence (ITS) analysis indicated that the materials collected in Mabul Island and Gusungan Island (both in Malaysia) and one population in Myanmar are actually $H$. major. In the field this kind of analysis is usually not possible, but our results suggest that careful analysis of seagrass samples need to be conducted before classifying them as $H$. ovalis.

The Indo-Pacific region has the largest number of seagrass species worldwide and this region was considered as the origin of the Hydrocharitaceae family [52,55]. Malaysia not only shows the highest number of Halophila species, summing up to seven species [17], this study, but also the highest diversity of $H$. ovalis haplotypes: there are four haplotypes found in six populations in Malaysia. In contrast, Nguyen et al. [23] found only one haplotype in four populations in Viet Nam. This finding is congruent with the hypothesis of Malaysia being the center of origin of the seagrasses.

\section{Genetic and geographic distance of $H$. ovalis based on SSRs}

The genetic diversity indices showed relatively high values from 0.298 to 0.306 . Compared to results reported from other studies on seagrass species including $Z$. marina (0.504 to 0.601$)$ [34], (0.310 to 0.460) [56], Zostera noltii Hornemann (0.442 - 0.630) [57], Posidonia oceanica (L.) Delile (0.191 to 0.363) [58] and Cymodocea nodosa (U.) Ascherson (0.286 to 0.564) [59], (0.383 to 0.647) [60] using SSRs markers showed that the genetic diversity of H. ovalis is lower. Unfortunately, there are no studies on the genetic diversity of $H$. ovalis based on SSRs markers for direct comparison so far. In other AFLP approaches of seagrass species the genetic diversity such as Thalassia testudinum Banks ex König $(\mathrm{H}=0.35,[32])$ is slightly higher or much lower than in our results, such as for Z. marina $(\mathrm{H}=0.007$ to $0.072,[61])$. Hence, the genetic diversity of seagrass varied indeed from species to species, geographic distribution, and different DNA fingerprinting approaches.

The present distribution of the genetic structure within species is influenced by evolutionary history [62]. In this study, genetic and AMOVA analyses indicated significant genetic differences among populations in the Western Pacific Ocean $\left(\mathrm{F}_{\mathrm{ST}}=0.483\right)$, among populations in the Eastern Indian Ocean $\left(\mathrm{F}_{\mathrm{ST}}=0.485\right)$, and larger significant differences among 14 populations surveyed in the Western Pacific Ocean and the Eastern Indian Ocean $\left(\mathrm{F}_{\mathrm{ST}}=0.679\right)$. All above results indicated that great genetic differentiation among populations was detected and/or gene flow among populations is very low. For the Celebes Sea, pair wise genetic differentiation among populations showed genetic differentiation although the geographic distance among populations is about 30 to $40 \mathrm{~km}$. However, genetic differentiation between MY-mg and MY-bd is very low (0.048) in contrast to other populations in the Celebes Sea. This could be explained by the diversity of the habitat such as substratum, currents, and time exposure to air during low tide etc., and those factors may affect the genetic differentiation. Japar et al. [17] stated that there are remarkable variations of $H$. ovalis, which grows in different substratum and depth. Significant genetic differences were also found in $Z$. marina between the Wadden Sea and the Baltic Sea where geographic distance among populations is within areas of 10 to $50 \mathrm{~km} \mathrm{[34].} \mathrm{Leaf} \mathrm{morphology}$ (small form) of $H$. ovalis collected in Tiga Island showed great differences in comparison to the other populations in the Celebes Sea (Prof. Japar, Malaysia, personal observation).

For the South China Sea, there are very great genetic differentiations among populations in the northern part of the South China Sea (HK-tc) and the remaining populations in the western, eastern and southern part of the South China Sea. Perhaps high latitude (or lower average temperature) in the northern part of the South China Sea may lead to the genetic differentiation. Both populations collected in Viet Nam also showed significant differences, although the geographic distance between two populations is less than $100 \mathrm{~km}$. In fact, there are great differences between the environmental conditions from two populations, in the lagoon and in the open sea. It could be explained by the differentiation of salinity, with high salinity (open sea) and low salinity (lagoon). The genetic difference between $H$. ovalis populations in the open sea and the lagoon were also found in India based 
on AFLP data [33]. For the population of the Gulf of Thailand, the results indicated low genetic differentiation between populations in Thailand and the western part of the South China Sea. Perhaps there was no geographic barrier found between the western part of the South China Sea and the Gulf of Thailand. A study of Morton and Blackmore [63] shows surface currents between the Gulf of Thailand and the western part of the South China Sea, that frequently occur in both summer and winter season.

The genetic differentiation between populations in the Andaman Sea and in the Bay of Bengal is significantly different. This could be explained by a very long geographic distance (more than 2,000 km) between the Bay of Bengal and the Andaman Sea. However, there is no significant genetic differentiation between populations of TH-tr and TH-sa in the Andaman Sea. Perhaps short geographic distances and the same habitat are the main causes that led to the high similarity between the two populations. Results from AFLP analysis also indicated that the genetic distance between populations from $\mathrm{TH}$ tr and TH-sa within the Andaman Sea is much lower than between populations from the Andaman Sea and the Gulf of Thailand. Moreover, surface currents in the winter (from TH-tr to $\mathrm{TH}$-sa) and in the summer (THsa to TH-tr) [63] support species dispersal between THtr and TH-sa. In contrast, genetic differentiation between populations from IN-ka and IN-ma was also high. It could be explained by the geographic distance as well as habitat differences (lagoon vs open sea).

The result from the unrooted neighbor-joining tree based on Slatkin's genetic distance showed the identified six main clusters corresponding to populations from different regions. Based on the genetic distance, the population in MY-jo seems to be in between the Western Pacific and the Eastern Indian Ocean, which corresponds to the geographic distribution of $\mathrm{H}$. ovalis populations in the study. However, one of the most striking results is the unexpected result in the case of the HK-tc population. It showed no simple relationship between genetic differentiation and distance between pairs of population. The HK-tc population was genetically closer to the population in the Eastern Indian Ocean than to populations in the Western Pacific Ocean. At present we are unable to explain this puzzling result.

Role of the Thai-Malay Peninsula as a geographic barrier to $H$. ovalis populations in Thailand based on AFLP analysis

Among a total of 231 bands, 208 (90.05\%) were polymorphic bands. This contrasts with a level of variability of $30 \%$ using AFLP in land plant species, such as rice [64]. In a recent study by Nguyen et al. [33] it was shown that the $17.5 \%$ of polymorphic bands are presented in the $H$. ovalis $-H$. ovata complex. High level of polymorphic bands has previously been reported in Thalassia testudinum Banks ex König [32] and Zostera marina Linnaeus [61] using AFLP. The percentage of polymorphic bands varies from species to species, geographic distribution, and primer combinations. For the band-based approach performed in this study, the similarity index showed comparable values to the similarity index of $\mathrm{H}$. ovalis populations found in India [33]. Comparison between clustering analysis (UPGMA) (Figure 4) and PCoA (Additional file 2) showed that the pattern of clustering the taxa was similar with both analyses: The individuals collected in the Gulf of Thailand clustered as single clade, whereas individuals collected in the Andaman Sea grouped together. AMOVA results (Table 6) also indicate this variation between two groups. In this study, pair wise genetic differentiation $\left(\mathrm{F}_{\mathrm{ST}}\right)$ and genetic distance (Additional file 3) among populations support the hypothesis that $H$. ovalis in the Gulf of Thailand and the Andaman Sea are genetically different. The results from AFLP analysis are also in agreement with the results of ITS analysis when different haplotypes in the Gulf of Thailand and the Andaman Sea were classified. In addition, the previous studies on marine animals $[12,13]$ and mangroves $[14,15]$ also indicated that the Thai-Malay peninsula is an effective geographic barrier for populations of different organisms in the Gulf of Thailand and the Andaman Sea.

Based on ITS, AFLP and SSRs analysis of genetic variation of $H$. ovalis, results indicated that the genetic markers are powerful tools to assess the genetic differentiation on the broad sample collection sites. However, the sample size was still low and in the case of TH-kn that may affect the standard error of the diversity in the population of the species as discussed by Singh et al. [65]. According to all our results, missing haplotypes were made visible in the haplotype network, hence we recommend the collection of more samples from populations in the Philippines, somewhere between the two mainlands of Malaysia (Peninsular Malaysia and East Malaysia), and somewhere between the Andaman Sea and the Bay of Bengal (Myanmar and Nicobar Islands) to be included in future studies.

\section{Conclusion}

Our study documented the new records of $H$. major for Malaysia and Myanmar. The study also revealed that the Thai-Malay peninsula is a geographic barrier of $H$. ovalis populations in the Western Pacific and the Eastern Indian Ocean. Characteristics of habitat are also an ecological barrier to the evolution of $H$. ovalis in the smaller scale area. 


\section{Methods}

\section{Sample collection, DNA extraction and morphological analysis}

Samplings of Halophila species were carried out at the Pacific Ocean and the Indian Ocean. Samples were collected from 17 populations belonging to eight regions depending on the geographic distribution. Regions were determined by long geographic distance (more than $1,000 \mathrm{~km}$ in this study) or geographic barrier. Region I (northern part of South China Sea): 1-Hong Kong (HK-tc). Region II (western part of South China Sea): 2-Van Phong (VN-vp), 3-Thuy Trieu (VN-tt). Region III (eastern part of South China Sea): 4-Sarawak (MY-sr). Region IV (Celebes Sea): 5-Tiga Island (MY-tg), 6-Mabul Island (MY-mb), 7-Gusungan Island (MY-gs), 8-Sibangat Island (MY-sb), 9-Bodgaya Island (MY-bd), 10-Maiga Island (MY-mg). Region V (Gulf of Thailand): 11-Kanom (TH-kn). Region VI (southern part of South China Sea): 12-Johore (MY-jo). All above six regions belong to the Pacific Ocean. Region VII (eastern part of Andaman Sea): 13-Satun (TH-sa), 14-Trang (TH-tr). Region VIII (northern part of Andaman Sea): 15-Myanmar (MM-gy). Region IX (Bay of Bengal): 16-Marakanam (IN-ma), 17-Kanyakumari (IN-ka). Details of each sampling site are presented in Figure 1 and Table 1. At each sampling point, plants containing root, rhizome and leaf were selected, and washed with seawater in the field to remove the epiphytes and debris attached to the plants. Each plant sample was placed in a single plastic bag and kept on ice. Plant material was transferred to the laboratory at the same day. In the laboratory, materials were re-washed with de-ionized water to remove seawater. One plant was divided into two parts, one part was pressed as a herbarium voucher specimen and the remaining part was desiccated in silica gel [66] for later DNA extraction. Parts with a length of 10 to $12 \mathrm{~cm}$ in a developmentally comparable state from five to ten different plants were haphazardly collected across the beds with a distance of 10 to $15 \mathrm{~m}$ among individuals. Materials desiccated in silica gel were brought to the Institute of Botany, Leibniz University Hannover, Germany, for further analysis. Eight to ten young leaves of each individual were homogenized by a bead mill (22 Hz, $2 \mathrm{~min}$ ), and $100 \mathrm{mg}$ of the fine powdered plant material was used for DNA extraction. DNA extraction was carried out using the Plant Nucleospin II Kit (Macherey \& Nagel, Düren, Germany) following manufacture's instruction with slight modifications according to Lucas et al. [21]. DNA quality was checked on agarose gels stained with ethidium bromide and the concentration was measured by a microplate reader with micro-volume plates (Synergy Mx Multi-Mode, BioTek, Germany).

For the morphological analysis, ten adult leaves collected from ten different individuals from each location were used for the analysis. The five most important and differentiating parameters of leaf morphology including lamina width, lamina length, number of paired cross veins, space between intra-marginal veins and the ratio of the distance between intra-marginal vein $(r)$ and lamina margin $(R)$ were measured under the microscope Olympus SZ (Olympus, Tokyo, Japan). Photographs were taken using a U-TV1X-2 digital camera (Olympus) connected to a computer. The test for equal variances of each data set of leaf morphology among groups was checked by Levene's test for homoscedasticity. Levene's test, one-way analysis of variance (ANOVA), Tukey test was carried out by Minitab software (State College, PA, USA). Specimens were identified using the keys of Kuo et al. [5].

\section{ITS amplification procedure and sequencing}

In this analysis, three individuals per population randomly selected from 15 populations (45 samples in total) described above were used for ITS amplification (Table 1). The region selected for PCR amplification was the nuclear ITS region including the $5.8 \mathrm{~S}$ sequence. Primer pairs used in this study were (ITS5a) [67] and (ITS4) [68] (Table 7) to amplify a sequence of 700 to 710 bp consisting of ITS1, $5.8 \mathrm{~S}$, and ITS2. The total volume of $25 \mu \mathrm{l}$ included 1x Dream Taq Green buffer, $0.2 \mathrm{mM}$ dNTPs, $2 \mathrm{mM}$ $\mathrm{MgCl}_{2}, 1 \mathrm{U}$ Taq polymerase (MBI Fermentas, St. LeonRot, Germany), 10 to 30 ng template DNA, 1 pmol primer each. The PCR was performed in a PTC 200 thermocycler (Biozym-Diagnostik GmbH, Hess. Oldendorf, Germany) with a heated lid under the following conditions: initial denaturation for $4 \mathrm{~min}$ at $95^{\circ} \mathrm{C}$ followed by 30 cycles of denaturation for $25 \mathrm{~s}$ at $95^{\circ} \mathrm{C}$, primer annealing for $30 \mathrm{~s}$ at $52^{\circ} \mathrm{C}$ and extension for $35 \mathrm{~s}$ at $72^{\circ} \mathrm{C}$, terminated by a final hold at $10^{\circ} \mathrm{C}$. All PCR reactions were repeated two to four times independently with the same individual to reduce errors, possibly created by the Taq polymerase, in the final consensus sequence to a minimum. Direct sequencing of PCR products was done by GATC Biotech (Konstanz, Germany) from both directions. Consensus sequence was achieved by Clone Manager 9 (Sci-Ed, Cary, NC, USA).

\section{SSRs procedure}

One hundred individuals (data given from Table 1) collected from 14 populations in the Pacific and the Indian Ocean were used for the analysis. Details of sample size, names of locations and coordinates are presented in Table 1. Among 10 primer pairs suggested by $\mathrm{Xu}$ et al. [70], we used five primer pairs resulting in highly polymorphic bands (HO5, HO8, HO36, HO48 and HO51) (Table 7) for PCR. Thirty ng of template DNA was used in each $15 \mu \mathrm{l}$ PCR including $1 \mathrm{x}$ Williams buffer, $0.2 \mathrm{mM}$ dNTPs, 1 U Taq polymerase (MBI Fermentas), and 1 pmol primer each. The PCR was performed in a PTC 200 thermocycler (Biozym-Diagnostik $\mathrm{GmbH}$ under the following conditions: initial denaturation for $5 \mathrm{~min}$ at 
Table 7 Sequence of primers/adaptors used for ITS, AFLP and SSRs

\begin{tabular}{|c|c|c|c|c|c|}
\hline Sequence of primers used for ITS & Name of primer & Ann. temp. $\left({ }^{\circ} \mathrm{C}\right)$ & Motive & Length of PCR product (bp) & Source \\
\hline 5'-CCTTATCATTTAGAGGAAGGAG-3' & ITS5a & 52 & & 700 & [67] \\
\hline 5'-TCCTCCGCTTATTGATATGC-3' & ITS4 & & & & {$[68]$} \\
\hline \multicolumn{6}{|c|}{ Sequence of adaptors and primers used for AFLP } \\
\hline 5'-CTCGTAGACTGCGTACC-3' & EcoRl adaptors & & & & [69] \\
\hline \multicolumn{6}{|l|}{ 5'-AATTGGTACGCAGTCTAC-3' } \\
\hline 5'-GACGATGAGTCCTGAG-3' & Msel adaptors & & & & \\
\hline \multicolumn{6}{|l|}{ 5'-TACTCAGGACTCAT-3' } \\
\hline 5'-GACTGCGTACCAATTCA-3' (ECORI + A) & Pre-selective primers & & & & \\
\hline \multicolumn{6}{|l|}{ 5'-GATGAGTCCTGAGTAAA-3' (Msel + A) } \\
\hline$E C o R I+A C A / M s e l+A T C$ (set1) & Final amplification & & & $50-500$ & \\
\hline \multicolumn{6}{|l|}{ EcoRl + ACC/Msel + ATC (set2) } \\
\hline \multicolumn{6}{|l|}{ EcoRI + ACA/Msel + ACA (set3) } \\
\hline \multicolumn{6}{|l|}{$E C o R I+A C C / M s e l+A C A(s e t 4)$} \\
\hline \multicolumn{6}{|l|}{ Sequence of primers used for SSRs } \\
\hline 5'-GAATGGGAAGGTGAAAGAG-3' & $\mathrm{HO} 5$ & 59 & $(\mathrm{AT})_{\mathrm{n}}(\mathrm{GA})_{\mathrm{n}}$ & $260-296$ & [70] \\
\hline \multicolumn{6}{|l|}{ 5'-CACGGCACTGTTCATCTAC-3' } \\
\hline 5'-ATAACCAAAGCCTCCCAAGC-3' & $\mathrm{HO} 8$ & 52 & $(G A)_{n}$ & 156-186 & \\
\hline \multicolumn{6}{|l|}{ 5'-AAATATCAAACGCCCCTCAC-3' } \\
\hline $5^{\prime}-$ CAACTAACCAAACGAGAAAC-3' & $\mathrm{HO} 36$ & 59 & $(\mathrm{GA})_{n} \mathrm{GC}(\mathrm{GA})_{n}$ & $220-240$ & \\
\hline \multicolumn{6}{|l|}{ 5'-AACCTTGACACCTGCTAATA-3' } \\
\hline 5'-ATCGAACCCAATAGACACCAG-3' & $\mathrm{HO} 48$ & 59 & $(G A)_{n}$ & $196-246$ & \\
\hline \multicolumn{6}{|l|}{ 5'-CAGGCAACTTAGCAAGAAACT-3' } \\
\hline 5'-AGATAAGTTTCACTCCTGTG-3' & $\mathrm{HO} 51$ & 46 & $(G A)_{n}$ & $141-175$ & \\
\hline 5'-ACCAGAACCAATCAAGAT-3' & & & & & \\
\hline
\end{tabular}

There are four primer pairs used for final amplification in AFLP and five primer pairs used to amplify five loci in SSRs. Ann. temp. Annealing temperature; bp, base pairs.

$94^{\circ} \mathrm{C}$ followed by 25 cycles of denaturation for $30 \mathrm{~s}$ at $94^{\circ} \mathrm{C}$, primer annealing for $30 \mathrm{~s}$ at 52 to $59^{\circ} \mathrm{C}$ and extension for $35 \mathrm{~s}$ at $72^{\circ} \mathrm{C}$, and terminated by a final hold at $10^{\circ} \mathrm{C}$. To each sample, $200 \mu \mathrm{l}$ of dye (98\% formamide, $10 \mathrm{mM}$ EDTA, $0.05 \%$ pararosaniline) was added. Reactions were heated up to $72^{\circ} \mathrm{C}$ for 5 min before loading onto 6\% AFLP gels (Sequagel XR, National Diagnostics, Hull, England). For running an AFLP gel on the 4300 DNA Analyzer (LI-COR, Biosciences, Germany) manufacture's instruction were followed. Base pair lengths obtained from visual analysis was resolved with previously published allele lengths [70] and sequencing was performed when necessary.

\section{AFLP procedure}

Samples were collected from three populations from the Andaman Sea and the Gulf of Thailand. Initially, 10 to 15 individuals per population were collected in Thailand for AFLP analysis. Unfortunately, DNA extracted from some plant samples was degraded. Degradation may have been caused by the humid and hot climate during the collection period in Thailand. Meudt et al. [71] indicated that use of degraded DNA could result in poor quality profiles with low reproducibility in AFLP analysis. Hence, only the samples retrieving high quality DNA were subjected for further experiments. According to Pruett and Winker [72], a sample size of 20 to 30 individuals is recommendable for genetic population studies. However, five to six samples are sufficient to obtain a standard error equal to $10 \%$ of the diversity in the population of the species [65]. In this study, there are four and twenty samples included from the Gulf of Thailand and the Andaman Sea, respectively, showing high quality of DNA.

Details of sample size, name of locations and coordinates are presented in Table 1. The AFLP procedure was carried out as reported by Vos et al. [69] with few modifications. In brief, genomic DNA (250 ng) was digested with two restriction enzymes in a total volume of $25 \mu \mathrm{l}$ including $5 \mathrm{U}$ EcoRI, $3 \mathrm{U}$ MseI, 1x Restriction Ligation (RL) buffer $(10 \mathrm{mM}$ Tris/ $\mathrm{HCl}, 10 \mathrm{mM} \mathrm{MgAc}, 50 \mathrm{mM}$ KAc, $5 \mathrm{mM}$ DTT, pH 7.5) for overnight at $37^{\circ} \mathrm{C}$. Adapters were 
prepared in a total volume of $5 \mu$ including $50 \mathrm{pmol}$ of MseI adapters, 5 pmol of EcoRI adapters, $0.5 \mathrm{mM}$ ATP and 1.2 $\mathrm{U}$ of T4 DNA ligase, and 1x RL buffer. The mix of digested DNA and adapters were incubated at $37^{\circ} \mathrm{C}$ for $3.5 \mathrm{~h}$ and then used as a template for PCR. The preselective PCR contained $5 \mu$ of template, $1 \mathrm{U}$ of Taq polymerase (MBI Fermentas, St. Leon-Rot, Germany), $0.25 \mathrm{mM}$ of each of the four dNTPs, 1x Williams buffer (10 mM Tris/ $\mathrm{HCl} \mathrm{pH} \mathrm{8.3,} 50 \mathrm{mM} \mathrm{KCl}, 2 \mathrm{mM} \mathrm{MgCl}$, $0.001 \%$ gelatine) and $50 \mathrm{ng}$ of EcoRI and MseI primers with one selective nucleotide (A) in a total volume of $50 \mu \mathrm{l}$. The PCR program consisted of twenty cycles of $30 \mathrm{~s}$ at $94^{\circ} \mathrm{C}, 30 \mathrm{~s}$ at $60^{\circ} \mathrm{C}$ and $1 \mathrm{~min}$ at $72^{\circ} \mathrm{C}$, followed by $10 \mathrm{~min}$ at $72^{\circ} \mathrm{C}$. An aliquot of the reaction mix was diluted 1:20 with $1 \mathrm{x}$ TE Buffer $(10 \mathrm{mM}$ Tris/ $\mathrm{HCl} \mathrm{pH} 7.5,1 \mathrm{mM}$ EDTA). The selective PCR contained $2.5 \mu \mathrm{l}$ of the diluted (1:20) product of the pre-selective PCR, $2 \mathrm{mM}$ dNTPs, and $5 \mathrm{U} \mathrm{Taq}$ polymerase in a total volume of $10 \mu \mathrm{l}$. Four primer pairs, $E c o \mathrm{RI}+\mathrm{ACA} / \mathrm{MseI}+\mathrm{ATC}, E c o \mathrm{RI}+$ $\mathrm{ACC} / M s e \mathrm{I}+\mathrm{ATC}, E c o \mathrm{RI}+\mathrm{ACA} / M s e \mathrm{I}+\mathrm{ACA}$ and $E c o \mathrm{RI}+$ $\mathrm{ACC} / \mathrm{Mse} \mathrm{I}+\mathrm{ACA}$, (Eurofins MWG Operon, Ebersberg, Germany) were used for the selective amplification. The first amplification cycle was carried out for $30 \mathrm{~s}$ at $94^{\circ} \mathrm{C}$, $30 \mathrm{~s}$ at $65^{\circ} \mathrm{C}$ and $1 \mathrm{~min}$ at $72^{\circ} \mathrm{C}$. In each of the following 11 cycles, the annealing temperature was reduced by $0.7^{\circ} \mathrm{C}$. The last 24 cycles were carried out at an annealing temperature of $56^{\circ} \mathrm{C}$, and the final extension step was carried out at $72^{\circ} \mathrm{C}$ for $10 \mathrm{~min}$. To each sample, $50 \mu \mathrm{l}$ of dye (see above) was added. Running conditions and instruments were the same as for SSRs.

\section{Bioinformatic analysis}

The obtained ITS sequences and known sequence of Halophila decipiens Ostenfeld (KC175913) and H. minor (AF366405; AF366406) were aligned by CLUSTAL X [42] and the alignment was further modified by eye. Gaps were considered as missing data. Identical sequences within each species were excluded from the alignment. Additional in-group sequences were obtained from GenBank (Table 1), and included in the alignment. The program jModelTest 0.1.1 [73] was used to find the model of sequence evolution that fitted best with the data set. Phylogenetic analyses were performed using ML, NJ [74] with the model Tamura 3-parameter, MP [75] in MEGA5.2 [46], and BA (Metropolis-coupled Markov chain Monte Carlo method) performed in MrBayes v.3.2 [76]. Halophila decipiens was used as out-group, because it is closer to its ancestor than the Halophila ovalis complex [7]. In the analyses, trees were tested by the bootstrapping method with 1,000 replications. All phylogenetic trees achieved from analysis were analyzed and exactly constructed by the "tree of trees" approach [77]. Moreover, a network of relationships among haplotypes was constructed as well as a cladogram that showed the nested structure of the haplotypes. This analysis was conducted in software TCS version 1.21 [78]. Only populations determined as $H$. ovalis based on ITS analysis were used for AFLP and SSRs analysis.

For the AFLP analysis, only polymorphic fragments were scored as binary data (1, band present; 0 , band absent). The binary scores were manually compared with the pictures to re-confirm presence or absence of bands. A presence/absence binomial matrix of 30 individuals and 201 polymorphic loci was used as basis for the analysis. In this study, the analysis with two approaches including band-based approach (for individual level) and allele frequency-based approach (for population level) [48] was carried out. In the individual level, the similarity among 30 individuals was calculated by the Dice coefficient [79]. A cluster analysis was performed using unweighted pair group method with arithmetic mean (UPGMA) based on the Dice index [79]. Bootstrap values (based on 1,000 re-samplings) were used to estimate the reliability of the clustering pattern. This analysis was carried out in FreeTree software [80]. The dendrogram was edited and displayed by MEGA5.2 [46]. Principal Coordinates Analysis (PCoA) of the correlation matrix was used to further investigate relationships between individuals using NTSYSpc version 2.20 [81]. At the population level, the allelic diversity at each locus was calculated as $h=1-\sum p_{i}^{2}$, where $p_{i}$ is the frequency of the $\mathrm{i}^{\text {th }}$ allele [49]. Allelic diversity within each population was the mean allelic diversities among the 114 loci. Nei's $\mathrm{G}_{\mathrm{ST}}$ [82] was used as a value of genetic differentiation. $\mathrm{G}_{\mathrm{ST}}$ was calculated using the formula $\mathrm{G}_{\mathrm{ST}}=\left(\mathrm{H}_{\mathrm{T}^{-}} \mathrm{H}_{\mathrm{S}}\right) / \mathrm{H}_{\mathrm{T}}$ [49], where $H_{T}$ represents the total gene diversity and $H_{S}$ represents the gene diversity within populations. Those values and the dendrograms (UPGMA) were assessed by POPGENE 3.2 [83] and MEGA5.2 [46]. In addition, pairwise genetic distances were calculated and used in AMOVA (Analysis of Molecular Variance, [43]). The analyses were conducted with the Arlequin version 3.5 [42].

For the SSRs, genetic diversity was measured for each site using the indices described by Williams and Orth [84]. These indices include: expected heterozygosity under Hardy-Weinberg equilibrium $\left(\mathrm{H}_{\mathrm{e}}\right)=(\Sigma$ expected frequency of heterozygotes at each locus)/(total number of loci); observed heterozygosity $\left(\mathrm{H}_{\mathrm{o}}\right)=(\Sigma$ frequency of heterozygotes at each locus)/(number of individuals); and allele richness $(\mathrm{A})=(\Sigma$ number of alleles at each locus $) /$ (total number of loci). All those parameters were assessed by Microsatellite Toolkit for Excel [39] and FSTAT version 2.9.3.1 [40]. Deviation from Hardy-Weinberg proportion was tested using a Markov-chain algorithm developed by Guo and Thompson [85] and implemented in the Genepop'007 [47]. Linkage disequilibrium among all pairs of loci for each population and all populations in the Western Pacific and the Indian Ocean was also tested by 
Genepop'007 [47]. For the population structure, Wright's F-statistics $\left(\mathrm{F}_{\mathrm{ST}}\right)$ was calculated. $\mathrm{F}_{\mathrm{ST}}$ measures the degree of inbreeding in the subpopulation relative to the total population, and is commonly used to estimate population differentiation. The software FSTAT version 2.9.3.1 [40] was also used for calculation. Significant differences among groups $\left(\mathrm{F}_{\mathrm{ST}}\right)$, among populations within groups $\left(\mathrm{F}_{\mathrm{SC}}\right)$ and within population $\left(\mathrm{F}_{\mathrm{CT}}\right)$ were test by AMOVA (Analysis of Molecular Variance). This analysis was carried out by Arlequin 3.5 [42]. Pairwise distances were calculated from allele frequency data using the Slatkin's distance [41] in Arlequin 3.5 [42]. The unrooted neighbor joining tree was constructed using neighbor joining with bootstrap resampling (1,000 replications) in package Phylip version 3.5 [44] and a consensus tree was created using FigTree version 1.3.1 [45]. The tree was edited and displayed in MEGA5.2 [46]. Geographic distances $(\mathrm{km})$ among populations were determined from NOAA digital map (Figure 1). The genetic-geographic distance matrix was statistically tested for correlation using the Mantel test [86]. This test was carried out by Genepop'007 [47].

\section{Availability of supporting data}

The data sets supporting the results of this article are available in the TreeBASE repository, http://purl.org/phylo/ treebase/phylows/study/TB2:S15597.

\section{Additional files}

Additional file 1: ITS sequences (ITS1-5.8S-ITS2) and their Genbank number (KF620337-KF620355).

Additional file 2: Principal Coordinate Analysis (PCoA) based on 208 AFLP markers. There are two groups including the Gulf of Thailand and the Andaman Sea. Clustering of TH-tr and TH-sa is not significant. Abbreviations as in Figure 1. Symbols as in Figure 4. The matrix plot is processed by NTSYSpc, 2.20 [81].

Additional file 3: Dendrogram of genetic distances among three populations of $\boldsymbol{H}$. ovalis. Branch lengths were calculated by Nei [87]. Abbreviations as in Figure 1. Symbols as in Figure 4. Dendrogram was assessed by POPGENE 3.2 [82], edited by MEGA5.2 [46].

\section{Competing interests}

The authors declare that they have no competing interests.

\section{Authors' contributions}

$J P, A P$ and NXV defined the research topic and the experimental design. NXV, MD, PT, USH, MHZ and JSP collected the materials. NXV and MD carried out the laboratory experiments and generated the data. JP and NXV analyzed the data and wrote the manuscript. All authors have contributed to, seen and approved the manuscript.

\section{Acknowledgements}

This work was financially supported by the Leibniz University Hannover, Hannover, Germany; the Ministry of Education and Training, Viet Nam; the Prince of Songkla University, the Higher Education Research Promotion and National Research University Project of Thailand; the Office of The Higher Education Commission, Universiti Putra Malaysia and Science Fund 04-01-04SF1171, Ministry of Science, Technology and Innovation (MOSTI), Malaysia. We are deeply indebted to Prof. Dr. T. Debener and Dr. M. Linde for giving technical and scientific advice on AFLP and SSRs analysis and for the possibility to use their equipment. We would like to thank Mr. Felix Hirschmann, Leibniz University Hannover, Germany, for correcting the English language and for collecting samples together with the esteemed colleagues at the Centre of Advanced Study in Marine Biology, Faculty of Marine Sciences, Annamalai University, India. Thanks to Prof. Put O Ang, Jr for sample collection in Hong Kong. We acknowledge support by Deutsche Forschungsgemeinschaft and Open Access Publishing Fund of Leibniz Universität Hannover.

\section{Author details}

'Institute of Botany, Leibniz University Hannover, Herrenhäuserstr. 2, D-30419 Hannover, Germany. ${ }^{2}$ Department of Marine Botan, Institute of Oceanography, Vietnam Academy of Science and Technology, 01 Cau Da Nha Trang City, Vietnam. ${ }^{3}$ Department of Biology, Faculty of Science, Prince of Songkla University, HatYai, Songkhla 90112, Thailand. ${ }^{4}$ Seaweed and Seagrass Research Unit, Excellence Centre for Biodiversity of Peninsular Thailand, Faculty of Science, Prince of Songkla University, HaiYai, Songkhla 90112. Thailand. ${ }^{5}$ Department of Marine Science, Mawlamyine University, Mawlamyine, Myanmar. ${ }^{6}$ Department of Animal Science and Fishery, Faculty of Agriculture and Food Sciences, Universiti Putra Malaysia Bintulu Sarawak Campus, Nyabau Rd, P.O. Box 386, 97008 Bintulu, Sarawak, Malaysia.

${ }^{7}$ Department of Aquaculture, Faculty of Agriculture, Universiti Putra Malaysia, 43400 Serdang, Selangor Darul Ehsan, Malaysia.

Received: 23 October 2013 Accepted: 25 April 2014

Published: 30 April 2014

\section{References}

1. Short FT, Polidoro B, Livingstone SR, Carpenter KE, Bandeira S, Bujang JS, Calumpong HP, Carruthers TJB, Coles RG, Dennison WC, Erftemeijer PLA, Fortes MD, Freeman AS, Jagtap TG, Kamal AHM, Kendrick GA, Kenworthy WJ, LaNafie YA, Nasution IM, Orth RJ, Prathep A, Sanciangco JC, Tussenbroek BV, Vergara SG, Waycott M, Zieman JC: Extinction risk assessment of the world's seagrass species. Biol Cons 2011, 144:1961-1971.

2. Nguyen XV, Bujang JS, Papenbrock J: Variability of leaf morphology and marker genes of members of the Halophila complex collected in Viet Nam. Aquat Bot 2013, 110:6-15.

3. Uchimura M, Fay EJ, Shimada S, Arai S, Inoue T, Nakamura Y: A reassessment of Halophila species (Hydrocharitaceae) diversity with special reference to Japanese representatives. Bot Mar 2008, 51:258-268.

4. Kuo JJ: New monoecious seagrass of Halophila sulawesii (Hydrocharitaceae) from Indonesia. Aquat Bot 2007, 87:171-175.

5. Kuo JJ, Kanomoto Z, lizumi H, Mukai H: Seagrasses of the genus Halophila Thours (Hydrocharitaceae) from Japan. Acta Phytotax Geobot 2006, 57:129-154

6. Shimada S, Watanabe M, Ichihara K, Uchimura U: Morphological variations of seagrass species, Halophila nipponica (Hydrocharitaceae, Alismatales). Coast Mar Sci 2012, 35:85-90.

7. Waycott M, Freshwater D, York R, Calladine R, Kenworthy W: Evolutionary trends in the seagrass genus Halophila (Thouars): Insights from molecular phylogeny. Bull Mar Sci 2002, 71:1299-1308.

8. Uchimura M, Faye EJ, Shimada S, Arai S, Inoue T, Nakamura Y: A re-evaluation of the taxonomic status of Halophila euphlebia Makino (Hydrocharitaceae) based on morphological features and ITS sequence data. Bot Mar 2006, 49:111-121.

9. Braillet C, Charmantier A, Archaux F, Dos Santos A, Perret P, Lambrechts MM: Two blue tit Parus caeruleus populations from Corsica differ in social dominance. Avian Biol 2002, 33:446-450.

10. Roy D, Kelly DW, Fransen CHJM, Heath DD, Haffner GD: Evidence of small-scale vicariance in Caridina lanceolata (Decapoda: Atyidae) from the Malili Lakes, Sulawesi. Evol Ecol Res 2006, 8:1087-1099.

11. Den Hartog C: The sea-grasses of the world. North-Holland: Amsterdam Publishing Company, Amsterdam/London; 1970.

12. Liao PC, Chiang YC, Huang S, Wang JC: Gene flow of Ceriops tagal (Rhizophoraceae) across the Kra Isthmus in the Thai Malay Peninsula. Bot Stud 2009, 50:193-204.

13. Su GH, Huang YL, Tan FX, Ni XW, Tang T, Shi SH: Genetic variation in Lumnitzera racemosa, a mangrove species from the Indo-West Pacific Aquat Bot 2009, 84:341-346.

14. Khamnamtong B, Klinbunga S, Menasveta P: Genetic diversity and geographic differentiation of the Giant Tiger shrimp (Penaeus monodon) 
in Thailand analyzed by mitochondrial $\mathrm{COI}$ sequences. Biochem Genet 2009, 47:42-55.

15. Zhang JB, Cai ZP, Huang LM: Population genetic structure of Crimson snapper Lutjanus erythropterus in East Asia, revealed by analysis of the mitochondrial control region. Mar Sci 2006, 63:693-704.

16. Short FT, Moore GE, Peyton KA: Halophila ovalis in the tropical Atlantic Ocean. Aquat Bot 2010, 93:141-146.

17. Japar SB, Muta HZ, Mohd Fl, Khairul AMS, Arshad A: Growth performance of Malaysia's spoongrass, Halophila ovalis (R. Br.) Hooker $f$. under different substrate, salinity and light regime. Coast Mar Sci 2010, 34:103-107.

18. McMillan C: Morphological diversity under controlled conditions for the Halophila ovalis-H. minor complex and the Halodule uninervis complex from Shark Bay, Western Australia. Aquat Bot 1983, 17:29-42.

19. Coles RG, Lee-Long WJ, McKenzie LJ, Roelofs AJ, De'ath G: Stratification of seagrasses in the GBR world heritage area, N.E. Australia, and implications for management. Biol Mar Medit 2007, 7:345-348.

20. Den Hartog C, Kuo J: Taxonomy and biogeography of seagrasses. In Seagrasses: Biology, ecology and conservation. Edited by Larkum AWD, Orth RJ, Duarte CM. Dordrecht, The Netherlands: Springer; 2006:1-23.

21. Lucas C, Thangaradjou T, Papenbrock J: Development of a DNA barcoding system for seagrasses: successful but not simple. PLOS ONE 2012, 7:e29987.

22. McDermid KJ, Gregoritza MC, Reeves JW, Freshwater DW: Morphological and genetic variation in the endemic sea grass Halophila hawaiiana (Hydrocharitaceae) in the Hawaiian Archipelago. Pac Sci 2003, 57:199-209.

23. Nguyen $X V$, Holzmeyer $L$, Papenbrock J: New record of the seagrass species Halophila major (Zoll.) Miquel in Viet Nam: evidence from leaf morphology and ITS analysis. Bot Mar 2013, 56:313-321.

24. Capiomont A, Sandmeier M, Caye G, Meinesz A: Enzyme polymorphism in Posidonia oceanica, a seagrass endemic to the Mediterranean. Aquat Bot 1996, 54:265-277.

25. Reusch TBH: Fitness-consequences of geitonogamousselfing in a clonal marine angiosperm (Zostera marina). Evol Biol 2001, 14:129-138.

26. Angel J: Genetic diversity of Halodule wrightii using Random Amplified Polymorphic DNA. Bot Mar 2002, 74:165-174.

27. Jover MA, del Casstillo-Agudo L, Garcia-Carrascosa M, Segura J: Random amplified polymorphic DNA assessment of diversity in western Mediterranean populations of the seagrass Posidonia oceanica. Am J Bot 2003, 90:364-369.

28. Kirsten JH, Dawes CJ, Cochrane BJ: Randomly amplified polymorphism detection (RAPD) reveals high genetic diversity in Thalassia testudinum banks ex Konig (Turtlegrass). Aquat Bot 1998, 61:269-287.

29. Procaccini G, Acunto S, Famà P, Maltagliati F: Structural, morphological and genetic variability in Halophila stipulacea (Hydrocharitaceae) populations in the western Mediterranean. Mar Biol 1999, 135:181-189.

30. Jewett-Smith J, McMillan C, Kenworthy WJ, Bird K: Flowering and genetic banding patterns of Halophila johnsonii and conspecifics. Aquat Bot 1997, 59:323-331.

31. Travis SE, Sheridan P: Genetic structure of natural and restored shoalgrass Halodule wrightii populations in the NW Gulf of Mexico. Mar Ecol Prog Ser 2006, 322:117-127.

32. Waycott M, Barnes PAG: AFLP diversity within and between populations of the Caribbean seagrass Thalassia testudinum (Hydrocharitaceae). Mar Biol 2001, 139:1021-1028.

33. Nguyen XV, Thangaradjou T, Papenbrock J: Genetic variation among Halophila ovalis (Hydrocharitaceae) and closely related seagrass species from the coast of Tamil Nadu, India - an AFLP fingerprint approach. Syst Biodiver 2013, 11:467-476.

34. Reusch TBH: Microsatellites reveal high population connectivity in Eelgrass (Zostera marina) in two contrasting coastal areas. Limnol Oceanogr 2002, 47:78-85

35. Reynolds LK, McGlathery KJ, Waycott M: Genetic diversity enhances restoration success by augmenting ecosystem services. PLOS ONE 2012, 7:e38397.

36. Krauss SL: Complete exclusion of nonsires in an analysis of paternity in a natural plant population using amplified fragment length polymorphism (AFLP). Mol ECol 1999, 8:217-226

37. Law JR, Donini P, Koebner RMD, Jones CR, Cooke RJ: DNA profiling and plant variety registration III: the statistical assessment of distinctness in wheat using amplified fragment length polymorphisms. Euphytica 1998, 10:335-342.

38. Kimberly AS, Toonen RJ: Microsatellites for ecologists: a practical guide to using and evaluating microsatellite markers. Ecol Lett 2006, 9:615-629.

39. Park SDE: The excel microsatellite toolkit: Trypanotolerance in West African cattle and the population genetic effects of selection (Ph.D. thesis). University of Dublin; 2001. Available at http://animalgenomics.ucd.ie/sdepark/mstoolkit.

40. Goudet J: FSTAT, a program to estimate and test gene diversities and fixation indices (version 2.9.3). 2001. Updated from Goudet (1995). Available from http://www2.unil.ch/popgen/softwares/fstat.htm.

41. Slatkin M: A measure of population subdivision based on microsatellite allele frequencies. Genetics 1995, 139:457-462

42. Excoffier L, Lischer HEL: Arlequin suite ver. 3.5: a new series of programs to perform population genetics analyses under Linux and Windows. Mol Ecol Resour 2010, 10:564-567.

43. Excoffier L, Smousee PE, Quanttro JM: Analysis of molecular variance inferred from metric distances among DNA haplotypes: application to human mitochondrial DNA restriction data. Genetics 1992, 131:479-491.

44. Felsenstein J: PHYLIP - phylogeny inference package (Version 3.2). Cladistics 1989, 5:164-166.

45. Morariu VI, Srinivasan BV, Raykar VC, Duraiswami R, Davis LS: Automatic online tuning for fast Gaussian summation. Advances in Neural Information Processing Systems (NIPS) 2008. http://tree.bio.ed.ac.uk/software/figtree/.

46. Tamura K, Peterson D, Peterson N, Stecher G, Nei M, Kumar S: MEGA5: molecular evolutionary genetics analysis using maximum likelihood, evolutionary distance, and maximum parsimony methods. Mol Bio Evol 2011, 28:2731-2739.

47. Rousset F: Genepop'007: a complete re-implementation of the genepop software for Windows and Linux. Mol Ecol Resour 2008, 8:103-106.

48. Bonin A, Ehrich D, Manel S: Statistical analysis of amplified fragment length polymorphism data: a toolbook for molecular ecologists and evolutionists. Mol Ecol 2007, 16:3737-3758.

49. Nei M: Analysis of gene diversity in subdivided populations. Proc Natl Acad Sci USA 1973, 70:3321-3323.

50. Annaletchumy L, Japar S, Muta HH, Arshad A: Morphology of Halophila ovalis (R.Br.) Hook. f. from Peninsular and East Malaysia. Pertanika J Trop Agric Sci 2005, 28:1-12.

51. Hedge S, Smith N, Unsworth RKF: Temporal and spatial morphological variability of the seagrasses Halophila ovalis and Halodule uninervis throughout the Great Barrier Reef region: Preliminary analysis, Report to the Marine and Tropical Sciences Research Facility. Cairns: Reef and Rainforest Research Centre Limited; 2009.

52. Short F, Carruthers T, Dennison W, Waycott M: Global seagrass distribution and diversity: a bioregional model. Exp Mar Biol Ecol 2007, 350:3-20.

53. Miki S: On the sea-grasses in Japan (II). Cymodocea and marine Hydrocharitaceae. Bot Mag Tokyo 1934, 48:131-141.

54. Soe-Htun U, San-Tha-Htun U, Mu-Mu-Aye D, Ni-Ni-Win D, Lei-Lei-Win D, Ohno M: Notes on seagrasses along Myanmar Coastal Regions. Bull Mar Sci Fish, Kochi Uni 2001, 21:13-22.

55. Chen LY, Chen JM, Gituru RW, Wang QF: Generic phylogeny, historical biogeography and character evolution of the cosmopolitan aquatic plant family Hydrocharitaceae. BMC Evol Biol 2012, 12:30.

56. Wyllie-Echeverria S, Talbot SL, Rearick JR: Genetic structure and diversity of Zostera marina (eelgrass) in the San Juan Archipelago, Washington, USA. Estuar Coast Shelf Sci 2010, 33:811-827.

57. Diekmann OE, Coyer JA, Ferreira J, Olsen JL, Stam WT, Pearson GA Serrão EA: Population genetics of Zostera noltii along the west Iberian coast: consequences of small population size, habitat discontinuity and near-shore currents. Mar Ecol Prog Ser 2005, 290:89-96.

58. Procaccini G, Orsini L, Ruggiero MV, Scardi M: Spatial patterns of genetic diversity in Posidonia oceanica, an endemic Mediterranean seagrass. Mol Ecol 2001, 10:1413-1421.

59. Alberto F, Arnaud-Haond S, Duarte CM, Serrão EA: Genetic diversity of a clonal angiosperm near its range limit: the case of Cymodocea nodosa at the Canary Islands. Mar Ecol Prog Ser 2006, 309:117-129.

60. Alberto F, Massa S, Manent P, Diaz-Almela E, Arnaud-Haond S, Duarte CM, Serrão EA: Genetic differentiation and secondary contact zone in the seagrass Cymodocea nodosa across the Mediterranean-Atlantic transition region. Biogeosciences 2008, 35:1279-1294. 
61. Li Y, Song N, Li WT, Gao TX: Population genetics of Zostera marina Linnaeus (Zosteraceae) based on AFLP analysis. Biochem Sys Ecol 2012 44:216-223

62. Hamrick JL, Godt MJW: Conservation genetics of endemic plant species In Conservation Genetics. Edited by Avise JC, Hamrick JL. New York: Chapman and Hall; 1996:281-304

63. Morton B, Blackmore G: South China Sea. Mar Pollut Bull 2001, 42:1236-1263.

64. Mackill DJ, Zhang Z, Redona ED: Level of polymorphism and genetic mapping of AFLP markers in rice. Genome 1996, 39:969-977.

65. Singh M, Chabane K, Valkoun J, Blake T: Optimum sample size for estimating gene diversity in wild wheat using AFLP markers. Genet Resour Crop Evol 2006, 53:23-33.

66. Chase MW, Hills $\mathrm{HH}$ : Silica gel: an ideal material for field preservation of leaf samples for DNA studies. Taxon 1991, 40:215-220.

67. Stanford AM, Harden R, Parks CR: Phylogeny and biogeography of Juglans (Juglandaceae) based on matK and ITS sequence data. Am J Bot 2000, 87:872-882

68. White TJ, Bruns T, Lee S, Taylor JW: Amplification and direct sequencing of fungal ribosomal RNA genes for phylogenetics. In PCR Protocols: A Guide to Methods and Applications. Edited by Innes MA, Delfand DH, Sninsky J, White TJ. New York: Academic Press; 1990:315-322.

69. Vos P, Hogers R, Bleeker M, Reijans M, Miranda H, Frijters A, Pot J, Peleman J, Kuiper M, Zabeau M: AFLP: a new technique for DNA fingerprinting. Nucleic Acids Res 1995, 23:4407-4414.

70. Xu NN, Yu S, Zhang FG, Tsang PKE, Chen XY: Microsatellite primers for Halophila ovalis and cross-amplification in $\mathrm{H}$. minor (Hydrocharitaceae). Am J Bot 2010, 97:e56-e57.

71. Meudt MH, Clarke CA: Almost forgotten or latest practice? AFLP applications, analyses and advances. Trends Plant Sci 2007, 12:106-117.

72. Pruett LC, Winker K: The effects of sample size on population genetic diversity estimates in song sparrows Melospiz amelodia. Avian Biol 2008, 39:252-256

73. Posada D: jModel test: phylogenetic model averaging. Mol Biol Evol 2008 25:1253-1256.

74. Saitou N, Nei M: The neighbor-joining method: a new method for reconstructing phylogenetic trees. Mol Biol Evol 1987, 4:406-425.

75. Felsenstein J: Phylogenies from restriction sites: a maximum-likelihood approach. Evolution 1992, 46:159-173.

76. Ronquist F, Huelsenbeck J, Teslenko M: MRBAYES 3.2: Bayesian phylogenetic inference under mixed models. Bioinformatics 2011, 19:1572-1574

77. Nye TMW: Trees of trees: an approach to comparing multiple alternative phylogenies. Syst Biol 2008, 57:785-794.

78. Clement M, Posada D, Crandall KA: TCS: a computer program to estimate gene genealogies. Mol Ecol 2000, 9:1657-1659.

79. Dice LR: Measures of the amount of ecologic association between species. Ecology 1945, 26:297-302.

80. Hampl V, Pavlicek A, Flegr J: Construction and bootstrap analysis of DNA fingerprinting based phylogenetic trees with the freeware program FreeTree: application to Trichomonad parasites. Inter J Syst Evol Microbiol 2001, 51:731-735

81. Rohlf FJ: NTSYS-pc: Numerical Taxonomy and Multivariate Analysis System version 2.2 Exeter Software. Setauket New York; 2005. Available at http://www.exetersoftware.com/cat/ntsyspc/ntsyspc.html.

82. Nei M, Chesser RK: Estimation of fixation indices and gene diversities. Anna Hum Genet 1983, 47:253-259.

83. Yeh FC, Yang R, Boyle TJ, Ye Z: Popgene 32, Microsoft Ware Windows based Freeware for Population Genetic Analysis Version 1.32. University of Alberta, Edmonton, Alberta, Canada: Molecular Biology and Biotechnology Centre; 2000. Available at http://www.ualberta.ca/ fyeh/popgene_download.html.

84. Williams SL, Orth RJ: Genetic diversity and structure of natural and transplanted eelgrass populations in the Chesapeake and Chincoteague Bays. Estuaries 1998, 21:118-128.
85. Guo SW, Thompson EA: Performing the exact test of Hardy-Weinberg proportion for multiple alleles. Biometrics 1992, 48:361-372.

86. Mantel N: The detection of disease clustering and a generalized regression approach. Cancer Res 1967, 27:209-220.

87. Nei M: Estimation of average heterozygosity and genetic distance from a small number of individuals. Genetics 1978, 89:583-590.

doi:10.1186/1471-2148-14-92

Cite this article as: Nguyen et al:: Genetic species identification and population structure of Halophila (Hydrocharitaceae) from the Western Pacific to the Eastern Indian Ocean. BMC Evolutionary Biology 2014 14:92.

\section{Submit your next manuscript to BioMed Central and take full advantage of:}

- Convenient online submission

- Thorough peer review

- No space constraints or color figure charges

- Immediate publication on acceptance

- Inclusion in PubMed, CAS, Scopus and Google Scholar

- Research which is freely available for redistribution

Submit your manuscript at www.biomedcentral.com/submit
C) Biomed Central 